\title{
THE FIRST OXFORD DEBATE ON THE ETERNITY OF THE WORLD*
}

In a Paris manuscript containing a copy of Richard Fishacre's Sentences-Commentary ${ }^{1}$ there appears at book two, distinction 12, chapter 3, a lengthy treatment of the problem of the eternity of the world ${ }^{2}$. The same text, with only minor variants, is found at the very end of a copy of the same commentary in a London manuscript ${ }^{3}$. Although missing from all the other manuscripts containing the second book of the Fishacre commentary, seven in number, a marginal comment in a Cambridge manuscript (henceforth $C$ ) notes its absence:

hic deest questio de creatione vel inchoatione mundi que scripta est una cum questione de luce in parvo volumine ante questionem de heresibus ${ }^{4}$.

The treatise on heresies to which the note refers is in all probability the opusculum by the same Fishacre, which survives only in a Vatican manuscript ${ }^{5}$.

* A version of this paper was delivered at the Thirty-First Annual Meeting of the Medieval Association of the Pacific, at the University of Hawaii at Manoa, 14 March 1997. The session was in honor of Professor Richard C. Dales.

1. Viz. Paris, BN lat. 15754.

2. Technically the question turns on the unending duration of the world, not its eternity (in the Boethian sense). However, common usage dictates that the latter term be retained.

3. Viz. London, BL Royal 10.B.VII, ff. $386^{\text {rb }}-388^{\text {va }}$. I will argue in the preface to my edition of Fishacre's Commentary that this manuscript is the earlier of the two and after the Vatican manuscript the most reliable witness. There is solid evidence, on the other hand, that the Paris manuscript was relatively early in the tradition; it belonged to Gerard de Abbeville, who died in 1271 and bequeathed the codex to the Sorbonne.

4. Viz. Cambridge, Gonville \& Caius Coll. MS 329/410, fol. 170v. In addition, a manuscript containing the same work and once belonging to the Dominican convent of San Domenico in Bologna, now Bologna Univ. MS $1546(=B)$, at the same place in the text reads as follows: "questionem de eternitate mundi que deest habes in alio volumine questionum...".

5. Cf. my edition, "Richard Fishacre's Super s. Augustini librum de haeresibus adnotationes: An Edition and Commentary", in: Archives d'histoire doctrinale et littéraire du moyen age 60 (1993), pp. 207-279. 
In the following distinction, also at chapter 3 , the above-mentioned Paris manuscript (henceforth $P$ ) features a question on light, likewise omitted from all other manuscripts save the London witness (henceforth $R$ ), where it again appears at the very end of the codex. This time $C$ has the following marginal note opposite the place in the text where the insertion begins in $P$ :

hic deest questio de luce que scripta est in parvo quaterno cum questionibus de heresibus ${ }^{6}$.

Based on all the evidence, my conjecture is that this quaternus, which is a kind of unbound notebook ${ }^{7}$, and which either has not survived or has not as yet been identified, is the repository of several of Fishacre's opuscula, representing the fruits of his activity during the years following the completion of his Sentences-Commentary (c. 1245) ${ }^{8}$ and his death in 1248. These writings are occasional in nature and most probably extracurricular, not forming a part of his lectures as regent master. This particular question on the eternal duration of the world would then have been copied from the quaternus onto several spare folia at the end of $R$ and later still inserted into an appropriate place in the commentary on the Lombard text by the scribe of $P^{9}$.

The discovery of this hitherto unknown treatise on the world's eternity, as it turns out, enables us at last to complete the account of the earliest recorded discussion at Oxford of what was later at Paris to become a litmus test of philosophical leanings. The fact, moreover, that significant portions of this text are cited verbotenus by Fishacre's nemesis, Richard Rufus of Cornwall, provides us with both a terminus ante quem and further evidence of Fishacre's authorship ${ }^{10}$.

6. $C$, fol. $175^{\mathrm{v}}$.

7. For the use of the term in the High Middle Ages cf. Louis J. Bataillon, «Exemplar, Pecia, Quaternus», in: Olga WeIJERS (ed.), Vocabulaire du livre et de l'écriture au moyen age, Turnhout 1989, pp. 206-219.

8. For the dating of Fishacre's Sentences-Commentary cf. Franz PeLSTER, «Das Leben und die Schriften des Oxforder Dominikanerslehrers Richard Fishacre (d. 1248)", in: Zeitschrift für katholische Theologie 54 (1930), p. 531, and R. James LONG, "The Science of Theology according to Richard Fishacre: Edition of the Prologue to his Commentary on the Sentences», in: Mediaeval Studies 34 (1972), pp. 73-74.

9. The more customary place in Lombard's work for such a discussion to take place was the first distinction of the second book, not the twelfth; cf. Richard C. Dales, Medieval Discussions of the Eternity of the World, Leiden 1990, pp. 37-38.

10. Cf. infra, pp. 64 sqq. 
As with so many other issues, the earliest Oxford master to venture an opinion on the question of the world's eternity was Robert Grosseteste ${ }^{11}$. In the course of commenting on the opening verses of Genesis in his Hexaemeron Grosseteste finds the occasion to respond to a opinion voiced most likely by a fellow Englishman, Alexander of Hales, then Master of Arts at Paris ${ }^{12}$. In a yet unpublished question on the eternity of the world Alexander argues that Aristotle's view could be reconciled with Christian belief in the temporal origin of the universe:

It is true that the view is attributed to Aristotle that the world was able to be perpetual and always to have existed. But it should be known that the phrase "the world always existed» can be understood as meaning that it never had a beginning, and in this sense it is not true; or it can be understood as meaning that the world is commensurate with the whole of time, and in this sense it is true that the world has always existed; and this is what Aristotle believed [emphasis mine]. For thus the adverb "always» refers only to the totality of time ${ }^{13}$.

To Grosseteste this smacked of false syncretism, and he initiates his treatment of the question in the Hexaemeron with a solemn warning against

11. Given the fact that Grosseteste's contribution to the question has been thoroughly studied, I will attempt here no more that a brief review of the current scholarship. The scholar to whom we are most indebted for our knowledge of the question is Dales, whose many studies culminated finally in the book-length study, Medieval Discussions (nt. 9), and its companion volume of texts, edited with Omar Argerami, Medieval Latin Texts on the Eternity of the World, Leiden 1991. Among his other studies cf. especially: Richard C. DALES, «Discussions of the Eternity of the World During the First Half of the Twelfth Century», in: Speculum 57 (1982), pp. 495-508; ID., «Robert Grosseteste's Place in Medieval Discussions of the Eternity of the World», in: Speculum 61 (1986), pp. 544-563, and ID., «Time and Eternity in the Thirteenth Century», in: Journal of the History of Ideas 49 (1988), pp. 27-45. Stephen F. Brown goes over the same ground in «The Eternity of the World Discussion at Early Oxford», in: A. Zimmermann et A. Speer (edd.), Mensch und Natur im Mittelalter (Miscellanea Mediaevalia 21/1), Berlin-New York 1991, pp. 260-263.

12. There are two extant versions of a disputed question which have been provisionally attributed to Alexander; cf. Richard C. DALES, «Robert Grosseteste's Place» (nt. 11), p. 549, and Victorinus Doucet, «The History of the Problem of the Authenticity of the Summa», in: Franciscan Studies 7 (1947), pp. 26-41 and pp. 274-312. These questions have been edited as part of an unpublished doctoral dissertation: Donald M. Nathanson, Alexandri de Hales Quaestiones 'De eternitate, evo, et tempore' et 'De duratione mundi', diss. University of Southern California 1986, pp. 21-115.

13. Paris, BN lat. MS 16406, f. $7^{\mathrm{vb}}$, and Bologna, Univ. MS 2554, f. $5^{\mathrm{vb}}$; cited from Richard C. DALES, «Robert Grosseteste's Place» (nt. 11), p. 549. 
certain moderns, philosophizing more vainly than those [Plato and Aristotle], who said that Aristotle in particular had not felt that the world lacked a beginning of time but agreed with the Catholic faith on this point and posited a beginning of time and of the world ... [and] who try, against Aristotle himself and his Commentator, and also the holy commentators, to make a Catholic of Aristotle the heretic, thinking with amazing blindness and presumption that they are able to understand more clearly and interpret more truly the meaning of Aristotle from corrupt Latin versions than could the philosophers, both pagan and Catholic, who knew the entire, uncorrupted, unexcerpted Greek text. And let them not deceive themselves and sweat in vain to make Aristotle a Catholic, lest they uselessly waste their time and mental powers ... and make heretics of themselves ${ }^{14}$.

This uncompromising view respecting the Philosopher's position on the eternity question forms the background for Grosseteste's own exposition. His first argument is from authority and from his catholic and omnivorous reading he marshals his sources, Greek and Latin, which he claims had access to the uncorrupted text of Aristotle. These sources, which include Boethius, Augustine, Ambrose, Pliny, John Chrysostom, John Damascene, and an unidentified Hexaemeron, ascribed to both Jerome and Bede, constitute almost the complete stock of authorities utilized by later writers on the subject ${ }^{15}$.

Following upon the arguments from authority, Grosseteste fashions several arguments from reason to show that the universe could not have been eternal, as Aristotle and his followers claimed. First, he points to a confusion in the minds of the "ancients» between eternity properly so called and endless duration or perpetuity. Because their minds' gaze (aspectus mentis) had not been cleansed of love for temporal things, the pagans could not think of eternity except by analogy with temporality. Perpetuity, however, a temporal mode, upon examination is revealed to be an impossibility, the analogies to the contrary notwithstanding ${ }^{16}$.

14. Robert Grosseteste, Hexaemeron 1.8.2-4 (edd. Richard C. Dales and Servus Gieben, Oxford 1982, pp. 58-61); again the translation is for the most part Dales's («Robert Grosseteste’s Place» [nt. 11], pp. 547-548). Roger Bacon later was to echo these same sentiments, with a particular animus directed toward the summa of Frater Alexander.

15. Richard C. DALES, «Robert Grosseteste's Place» (nt. 11), pp. 551-552.

16. Grosseteste, Hex. 1.8.5 (edd. Dales / Gieben, p. 61). 
The pagans and their Christian fellow travelers, moreover, fail to understand that cause and effect with respect to eternity and time fall under two distinct measures. Therefore, says Grosseteste, analogies such as the footprint in the dust are not valid when applied to the eternal:

If the cause and what is caused do not share in the same kind of measure of being, this rule does not apply to them, namely that if the cause exists, the caused necessarily coexists. Therefore, since God is eternal, and the world and motion and time are temporal, time and eternity are not of the same kind of measure. ... The eternal God is the cause of the temporal world and time, but $\mathrm{He}$ precedes them not with respect to time, but with respect to simple eternity ${ }^{17}$.

Grosseteste's final argument in the Hexaemeron was a commonplace in the Islamic-Jewish tradition ${ }^{18}$ : namely, if the world were eternal and if the human race were coeternal, either an infinite number of human souls would have by now been generated or single soul would serve for all bodies or souls would be recycled into other bodies - each of which is patently impossible ${ }^{19}$.

When Fishacre composed his extracurricular question on the eternity of the world, he clearly had Grosseteste's Hexaemeron on the desk before $\operatorname{him}^{20}$. The piece opens with a reflection on the first verse

17. Grosseteste, Hex. 1.8.6 (edd. Dales / Gieben, pp. 61-62); cf. Richard C. DALES, «Robert Grosseteste's Place» (nt. 11), p. 554, and ID., «Time and Eternity» (nt. 11), p. 32. Cf. Augustine, Conf. 12.29 for the possible inspiration for the argument. It is, however, unclear precisely what Grosseteste means here by God's preceding the world with respect to simple eternity; he was to clarify the issue somewhat in his later De finitate, a work to which Fishacre may possibly have had access (cf. infra, nt. 33).

18. The argument is to be found in Algazel, Avicenna, and Maimonides; cf. Richard C. Dales, «Robert Grosseteste's Place» (nt. 11), p. 557. Cf. also Richard Sorabji, Time, Creation and the Continuum, Ithaca NY 1983, pp. 202-203.

19. Grosseteste, Hex. 1.8.7 (edd. Dales / Gieben, p. 62); cf. Richard C. Dales, «Robert Grosseteste's Place» (nt. 11), pp. 557-58. It should be added that Grosseteste entertains the same question on the world's duration in a little treatise, written about the same time as the Hexaemeron and later appended to his Physics commentary, namely the De finitate motus et temporis; cf. the edition by Richard C. DALES, «Robert Grosseteste's Treatise 'De finitate motus et temporis'”, in: Traditio 19 (1963), pp. 245-266. For Richard Rufus's use of the same work cf. Rega WoOD, «Richard Rufus of Cornwall on Creation: The Reception of Aristotelian Physics in the West», in: Medieval Philosophy and Theology 2 (1992), p. 25.

20. Cf. Richard C. DALES, «The Influence of Grosseteste's 'Hexaemeron' on the 'Sentences' Commentaries of Richard Fishacre O.P. and Richard Rufus of Cornwall, O.F.M.», in: Viator 2 (1971), pp. 271-300. Cf. R. James LoNG, «Richard Fishacre's Treatise De libero arbitrio», in: B. C. BAZÁn et al. (edd.), Moral and Political Philosophies in the Middle Ages, vol. 2, Ottawa 1995, pp. 879-891, for other instances. 
of Genesis, "In the beginning God created the heavens and the earth", a text which is cited by the Lombard and which thereafter provided the occasion for all of his commentators to discuss the question of the world's eternity. Observing that the literal sense of the Scriptures is manifold, Fishacre wonders about the many meanings of «beginning» (principium). Reflecting on the beginning of time, moreover, he asks with Grosseteste why the world was created at the vernal equinox and not at the autumnal, here adding original arguments of his own ${ }^{21}$.

The philosophical issue is joined, however, when Fishacre names the thinkers (Aristotle, Plato, Apuleius, and Pliny) who held that the world was eternal, having neither beginning nor end, and therefore coeternal with God. Departing now from the Grosseteste text, Fishacre distinguishes several variants of the pro-eternity position: first, that the world is coeternal with God in such wise that it is in no way $a b$ alio and therefore is not created; second, that the world is coeternal with God, yet is made by God - eternally. This latter has two subspecies: that the world is from an unwitting God, a God who necessarily emanates being; or that the world is made by a God who wills that the world be coeternal with $\mathrm{Him}^{22}$.

Fishacre's methodology will be to rehearse the arguments in favor of the first variant, that the world namely is uncreated and therefore eternal, then to refute them one by one, and then finally to offer some arguments that demonstrate the contrary, namely that the world is temporal in origin. In part borrowed from Maimonides ${ }^{23}$ and Alexander of Hales ${ }^{24}$, the arguments that Fishacre finds in support of the world's eternal duration are eight in number. God is, to begin with, the supreme good (and the good is according to the prevailing

21. Cf. infra, Appendix A, pp. 70-71, nn. 8-12.

22. Ibid., pp. 73-74, n. 16 .

23. Cf. Moses Maimonides, The Guide of the Perplexed 2.14 (tr. Shlomo Pines, vol. 2, Chicago 1963, pp. 285-289). Although it cannot be established that Fishacre had access to the work, Wolfgang Kluxen has argued convincingly that there existed a Latin version of Maimonides's Guide as early as 1230-1235; cf. Wolfgang KLUXEN, "Literargeschichtliches zum lateinischen Moses Maimonides", in: Recherches de Théologie ancienne et médiévale 21 (1954), pp. 23-50. Fishacre refers to Maimonides only once by name (viz. "Rabbi Moyses») in the Sentences Commentary (2.14.4), and it is by way of reporting (not quoting) Rambam's view on the impossibility of comparison except within the same species.

24. Cf. supra, nt. 12. 
myth self-diffusive); since God is also eternal, and hence his goodness is eternal, this is sufficient cause of an eternal effect, which is the world ${ }^{25}$.

Furthermore, continues Fishacre, since the eternal is better than the non-eternal, either God could have created a world coeternal with Himself or not. If $\mathrm{He}$ could not, $\mathrm{He}$ was not omnipotent. If $\mathrm{He}$ could, but willed not to, He was envious - which likewise violates the Platonic myth. Therefore, God could and did create eternally ${ }^{26}$.

Thirdly, three things are required for action: power, wisdom, and will. God not only has these three requisites, $\mathrm{He}$ is omnipotence, omniscience, and supreme will. But infinite power produces finite act instantaneously. Therefore, if an agent of infinite power is also eternal, its act is coeternal ${ }^{27}$.

The fourth argument he extracts from the Metaphysics, the fifth from the Physics. If according to the latter motion began to be when previously there was no motion, a mover also began to be where before there was no mover. But the nature of the divine substance precludes coming-to-be. If, however, this substance is first not moving, then moving, we say that it has undergone a change. Therefore there can be no first mover. This, however, is impossible. Therefore, the divine substance, which for the Christian is God, is always moving ${ }^{28}$.

The sixth argument is similar. If God is ever the same, what reason can be assigned that $\mathrm{He}$ is creating now rather than before, or indeed before that? On the part of the Creator there is no reason why creation takes place at this instant rather than before, and of course there could be no reason on the part of that which is to be made, since before it was made it was nothing. Thus either God never created - and therefore there is nothing now in being - or He created from eternity ${ }^{29}$.

25. Appendix A, p. 74, n. 17. Cf. AleXAnder of Hales, De duratione mundi (ed. NATHANSON, pp. 70-71).

26. Ibid., p. 74 , n. 18.

27. Ibid., pp. 74-75, n. 19. Cf. Maimonides, Guide (tr. Pines, p. 288), and AleXanDER OF HALES, De duratione mundi (ed. NATHANSON, pp. 68-69).

28. Ibid., p. 75, nn. 20-21. Cf. Maimonides, Guide (tr. Pines, p. 286). Cf. also Philip the Chancellor, Summa de bono, q. 3 (ed. Nicolaus Wicki, vol. 1, Berne 1985, pp. 47-48).

29. Ibid., p. 75, n. 22. Cf. Maimonides, Guide (tr. Pines, pp. 287-288). 
Seventhly and most subtly, of everything that has a beginning it is true to say that it once did not exist. Therefore if there is a first instant of time, in that instant which we will call $a$ it is true that the world exists. The proposition the world does not exist is thus true either in the same instant or in another. That it is true that the world in the same instant both exists and does not exist, however, is impossible. But affirmation and negation as the termini of generation are less distant than those which are the termini of creation. The former have in common at least matter, the principle of potentiality; the latter, since creation is ex nibilo, have nothing in common. If therefore the being and non-being which are the termini of generation cannot coexist at the same time, how much less can the absolute being and absolute non-being which are the termini of the act of creation? Therefore it is true that non-being is at another instant preceding the first instant, and between these, as between any two instants whatsoever, the medium is time. Therefore, before the first instant of time ... is time. Therefore - the only way out of the muddle the world has existed from eternity ${ }^{30}$.

In reply to the first argument, predicated on the necessary selfdiffusiveness of the good, Fishacre distinguishes two causes or principles, the natural and the voluntary: the former is "precipitate» (impetuosum), the latter is "reflective» (considerosum). The very positing of a sufficient natural cause, therefore, entails immediate action, whereas such is not the case with a voluntary cause, which is characterized not by necessity but by contingency. Thus the will is ever empowered to opt for the opposite (valet ad opposita), empowered namely to act or not to act. It does not therefore follow that a sufficient, eternal cause necessarily entails an eternal effect ${ }^{31}$.

With respect to the second argument, the argument based on the Timaeus account, Fishacre denies that God's «inability» to create a world or any creature coeternal with Himself connotes impotence; the opposite is rather the case. If God were to produce the creature from His own substance, as the Father generates the Son, it would indeed count as a defect if the product did not measure up to the producer. But God creates not out of Himself but out of matter or out of 
nothing. The non-eternity of the world, therefore, is a deficiency not on the part of the agent but rather on the part of the product ${ }^{32}$.

The third objection is joined on two fronts. As above, God's causality is voluntary, and thus His act is not necessarily co-existent with Himself. In addition, there are "those of great authority» ${ }^{33}$ who point out that time and eternity are different measures, and therefore a temporal effect is not necessarily conterminous with an eternal cause, no matter the infinite power of the latter ${ }^{34}$.

To the fourth and fifth objections Fishacre insists on the distinction between motion and the mover. The former begins to be, because it is not first by nature; the latter by contrast had no beginning, being by nature first. The eternity of the mover, moreover, does not at all entail the eternity of motion. Just as the sun can now illumine an object which before was not illumined without any change in the sun (as when a thing is conveyed from shelter into the sun's light), so too an agent can effect a change without itself undergoing a change ${ }^{35}$.

To the sixth argument Fishacre responds in two ways. First, the reason God created when he did and not before (as He creates this soul now and not before) is because it was best that it be done this way. Why? because God willed it. God does not will something because it is good - as is our mode of operating — but something is good precisely because God wills it $^{36}$.

The second response of Master Richard is that the question ("why did God make the world now and not before») is based on a false imagination, imagining namely that there is time before the world's creation. It is as mindless as asking why the world was made here in

32. Ibid., p. 77, n. 26.

33. "Those of great authority» are most likely GROSSETESTE, Hex. 1.8.6 (edd. Dales / Gieben, pp. 61-62); and Alexander of Hales, De eternitate (ed. Nathanson, p. 58). Richard Dales (in a private correspondence) saw in this passage a reference to the former's De finitate (ed. DALES, pp. 260-261).

34. Appendix A, p. 78, nn. 27-28.

35. Ibid., pp. 78-79, nn. 30-32. Cf. the explanation infra: «... sicut sol posset incipere illuminare nec tamen incipere lucere, et hoc non per suam sed rei illuminatae mutationem, sic Deus incepit esse movens et movere sine sui mutatione per mutationem mobilis. Neque tamen incepit intelligere, neque novo sed aeterno consilio fecit omnia quae temporaliter facta sunt», ibid., p. 80, n. 35. Cf. AleXANDER OF Hales, De duratione (ed. NATHANSON, p. 95).

36. Cf. Maimonides, Guide 2.18 (tr. Pines, pp. 301-302). 
this place rather than somewhere else, again falsely imagining that beyond this world there is infinite space ${ }^{37}$.

To the seventh and subtlest of the objections it must be noted, says Fishacre, that although other verbs consignify time, the verb est does not ${ }^{38}$. One must rather discern whether the word «now» (nunc) signifies the now of eternity or the now of time.

For unless the now of time is meant, this sentence would be false: «a man is». However, unless the now of eternity is meant, this would be false: "God is», and God would not have said «I am who am» ${ }^{39}$.

If therefore in every created thing non-being precedes being, in some of them non-being precedes being in temporal sequence (as in the souls that are now being created), but in others non-being precedes being only with respect to nature. The proposition non-being is prior to being, therefore, is not affirmed and denied with respect to the same measure ${ }^{40}$.

Since at the first now of time there was true being and since being implies non-being, the question is whether there was non-being at the same instant or at another. The answer for Fishacre is both. But the other now is not of the same genus; it is namely the now of eternity, different from the now of time ${ }^{41}$.

Regarding the objector's conclusion that between any two instants the medium is time, Fishacre notes that this is true only within the same genus. Between the now of time and the now of eternity, however, there is no medium, since the now of eternity is whole in any now of time, just as the soul is whole in any part of the body. Fishacre is here worth quoting:

37. Appendix A, pp. $80-81$, n. 36 . The implication here is that place is defined by the ultimate containing sphere, the empyrean, so that beyond the ultimum continens talk of place is unintelligible. Cf. Edward Grant, Physical Science in the Middle Ages, New York 1971, pp. 73-74.

38. Cf. Peter Lombard's discussion regarding the consignification of nouns and verbs (1 Sent. 44.2.1-4), Fishacre's likely source. On the truth value of propositions with the verb «is» cf. SorabJI, Time (nt. 18), pp. 50-51.

39. Appendix A, p. 81, n. 37.

40. Ibid., p. 81, n. 38.

41. Ibid., p. 81, n. 39. As Dales explains with respect to a similar argument in the $D e$ finitate: «But if the non-being of the world is in eternity and its being in time, it would seem that from the standpoint of the eternal (i.e. God) the world is not, unless one introduces 'before and after' into eternity, ..." (Medieval Discussions [nt. 9], p. 74). 
I said above, and I think what I said is true, that in the same "now» the being and the non-being of the first creature exist simultaneously; and generally speaking in all those things created from nothing, although non-being precedes being according to nature, they exist nevertheless at the same time, that is in the same instant of time ${ }^{42}$.

Therefore in the first instant of time it was true that the first creature existed and did not exist; nevertheless non-being is prior in nature to being, just as the same light in the same now of time is in the east and west, yet is prior by nature in the east.

The objection that the being and non-being which are the extremes of creation are more distant than the extremes of generation is thus solved. Although the extremes of generation are indeed less distant, nevertheless they do not share the same now of time, because they exist by reason of different nows of time. For different being causes different nows. But in the non-being that is one extreme of generation is a different being from that being which is the other extreme of generation. But extremes of creation, namely being and non-being, indeed share the same now of time, because, as has been said, they do not exist in any way by reason of diverse nows; for in the non-being which is the extreme of creation there is no being. Moreover, although created being necessarily requires an instant of time, the non-being preceding creation, to the extent that it is a pure nothing (pure nibil), just as necessarily requires that it not be measured by an instant ${ }^{43}$.

Now that Fishacre has disposed of the arguments in favor of the world's eternity, he finds ten arguments in support of the position that the world was created in time. There is little that is original in these arguments, most being restatements of the tradition from Alexander to Philip the Chancellor. Most, moreover, will resurface again in the writings of Bonaventure and other anti-Aristotelians.

The first argument is simply the opposition between time and eternity. On no less an authority than St. Augustine, the world is temporal, measured by time, and therefore not eternal ${ }^{44}$.

42. Appendix A, p. 82, n. 41. Rufus characterizes this argument as a subtlety which by his lights is not true: «... isti idem addunt aliquid de subtili quod non verum esse intelligo" (ed. BROWN, p. 273). Rufus, however, could have found the same "subtle» argument in the De finitate. Cf. ROBERT GROSSETESTE, De finitate motus et temporis (ed. DALES, pp. 260-261).

43. Appendix A, pp. 82-83, nn. 42-43.

44. Ibid., pp. 83-84, n. 45. 
Second, on the authority of Aristotle being and possibility in perpetual beings are identical. A fortiori is it the case in eternal beings. This means that such beings are immutable, otherwise they would not be everything that they can be. But the world is in constant flux. Therefore, etc. ${ }^{45}$.

The third is the well-worn versio argument, attributable originally to John Damascene ${ }^{46}$, namely that everything that is reducible to nothing was nothing before it was something. But the world is reducible to non-being, because on Plato's authority everything that is joined together is by nature dissoluble. Therefore the world had non-being before being. But this would have been impossible had it been eternal. Therefore, etc. ${ }^{47}$.

Fishacre follows with several per impossibile arguments, that are likewise commonplaces. If, for example, humankind existed from the beginning (here echoing Grosseteste), there would by now have been born an infinite number of human beings ${ }^{48}$. There would then be an infinite number of souls in existence (per impossibile according to Aristotelian canons) or else there would be one single soul for all mankind (as per Averroes) or a finite number of souls would successively occupy different corruptible bodies (as per Plato) — all of which are impossibile ${ }^{49}$.

Likewise, if Aristotle is correct, moderns are more perceptive than their forebears; but after an infinite duration our contemporaries should by this argument be infinitely perceptive - which of course belies experience. Therefore, etc. Also humans are decreasing in size generation by generation, and although any quantum is infinitely divisible, a certain modicum is necessary to preserve corporeity. Therefore, etc. Lastly, the population is increasing over time; over an infinite duration the number of humans would have occupied the finite space on the planet ${ }^{50}$.

In his seventh argument Fishacre maintains that any infinite series of agent causes is reducible to three orders, each succeeding the prior:

45. Ibid., p. 84, n. 46.

46. Cf. Dales / Argerami, Medieval Latin Texts (nt. 11), p. 91.

47. Appendix A, p. 84, n. 47.

48. Cf. Wood, «Richard Rufus» (nt. 19), pp. 10-12.

49. Appendix A, pp. 84-85, n. 48.

50. Ibid., pp. 85-86, nn. 49-52. 
call them $a, b$, and $c, b$ deriving of $a$ and $c$ deriving of $b$. It is agreed that without $b$ there would be no $c$ and without $a$ no $b$. Therefore without a first, none of the remaining (even if the series be infinite) would exist. Therefore the world had a first, a beginning ${ }^{51}$.

The eighth and ninth arguments make essentially the same point. For his tenth argument, however, Fishacre considers the grades of being: those that have neither beginning nor end (God), those that have both beginning and end (plants), and those that have a beginning but no end (souls). The remaining kind, those with an end but no beginning, is unknown. Therefore if all the heavenly revolutions which have taken place end with the present revolution, they necessarily had a first ${ }^{52}$.

Therefore, (paraphrasing Grosseteste) with a single word, principium, Moses has destroyed the errors of the philosophers, all of whom posited many principia ${ }^{53}$.

He [Moses] by a single letter shattered the errors of all of these <philosophers>, namely the final letter of this word, principio, by which is designated a singular number. Marvelous indeed is the inscrutable depth of this wisdom ${ }^{54}$ which by a single letter lays low a host of errors. Nor is it necessary to press for the destruction of these errors, since they are mutually self-destructing ${ }^{55}$.

The next Oxford master to take up the question of the world's eternal duration was the Franciscan master, Richard Rufus ${ }^{56}$. Although he honored the scholastic convention of not referring to his opponents by name - Fishacre is referred to as aliqui or quidam - Rufus clearly has the Fishacre text before him as well as Grosseteste's Hexaemeron ${ }^{57}$.

51. Ibid., pp. 86-87, n. 55.

52. Cf. Philip the Chancellor, Summa de bono, q. 3 (ed. Wicki, p. 51). Appendix A, p. 87, n. 58 .

53. Appendix A, pp. 87-88, n. 59.

54. The allusion here is to the text with which Fishacre begins his inaugural lecture and which opens his Commentary, "O altitudo divitiarum sapientiae et scientiae Dei» (Ro. 11,33).

55. Appendix A, pp. 88-89, n. 60.

56. Cf. the recent edition by Stephen BROWN, "The Eternity» (nt. 11), pp. 269-80. Cf. also Peter RaEDTs, Richard Rufus of Cornwall and the Tradition of Oxford Theology, Oxford 1987, pp. 187-200, and Rega WooD, «Richard Rufus» (nt. 19), pp. 23-30, and EAD., "Richard Rufus: Physics at Paris before 1240", in: Documenti e studi sulla tradizione filosofica medievale 5 (1994), pp. 87-127.

57. I have reproduced the Rufus text infra in Appendix B, italicizing the portions that are quoted from Fishacre. I also made several corrections to the edited text after examining the manuscript in situ. 
Rufus's approach is to articulate the arguments opposed to creation — seventeen by one reckoning ${ }^{58}$ — and to respond to each in turn. Of these arguments three are quoted verbotenus along with their proposed solutions from Fishacre's treatise, two others are paraphrased.

To the argument that a full and total cause necessarily produces a similarly eternal and therefore coexistent effect, Fishacre had wondered whether Grosseteste's solution had been sufficient

since a temporal cause can make it such that its act or motion is contemporaneous with it. If I claim that the latter be a sufficient cause, why cannot it be similarly the case that an eternal sufficient cause be able to produce its act coeternally with itself, since an eternal cause is infinitely more powerful than a temporal cause? ${ }^{59}$.

Fishacre, in short, as Maimonides before him and Thomas Aquinas after him, was distinguishing causal from temporal sequence: the Creator could have caused the world to be coeternally with Himself. Rufus's response to Fishacre's animadversion, however, is abruptly dismissive:

This question seems to me a nullity, since this is to ask why God could not make the temporal eternal ${ }^{60}$.

This is of course to miss the point, as is clear from Rufus's alternate response, which stresses the voluntary nature of the divine cause ${ }^{61}$.

Rufus likewise objects to Fishacre's response to the objection that if there is no good reason why God should not have created the world earlier (or later), the world was eternal. Fishacre had argued that the problem was based on a false imagination ${ }^{62}$. This question is likewise a nullity, responds Rufus. The more fundamental question is why God did not create the world from eternity. The answer is that such was God's eternal will, that namely the world come to be in time ${ }^{63}$.

58. Cf. RAEDTS, Richard Rufus (nt. 56), p. 193.

59. Cf. Appendix B, p. 91, n. 6: "Sed vellem ab eis doceri. Non enim intelligo, si iam sufficit haec eorum responsio, cum causa temporalis possit facere suum actum vel motum esse simul secum tempore. Si dico sit sufficiens causa, quare non similiter causa aeterna sufficiens possit facere suum actum sibi coaeternum, cum causa aeterna in infinitum sit potentior causa temporali?».

60. Ibid.

61. Ibid., p. 91, n. 7.

62. Cf. supra, pp. 60-61.

63. Cf. Appendix B, p. 92, n. 10. Cf. RaEDTs, Richard Rufus (nt. 56), p. 194. Raedts, however, mistakingly attributes the source of the argument to an anonymous commentary on the Metaphysics. 
Fishacre's seventh argument, moreover, Rufus also cites verbotenus, but objects again to his response:

But these same <masters> add something subtle which I understand not to be true, for they say that «in the first 'now' of time the being and the nonbeing of the first creature exist simultaneously...» ${ }^{64}$.

Equally objectionable to Rufus is Fishacre's view that non-being is prior in nature to being, as illustrated by light being at the same instant in the east and the west, though by nature prior in the east. He has refuted this view in the first book of his Commentary, says Rufus: presence in more than one place at the same time is impossible both for light and for angels $s^{65}$.

Rufus is also bothered by what he sees as Fishacre's claim that affirmation and negation can both be true of the same object at the same time. The mind cannot in any way grasp this («nec hoc capit intellectus aliquis omnino"), he says ${ }^{66}$.

Rufus has obviously subjected the Fishacre text to a close reading. Agreeing with his conclusions, Rufus feels nevertheless that several of his rival's arguments are defective - or at best so subtle that they lose any pedagogic value. In at least one instance, Rufus simply fails to understand the argument ${ }^{67}$. To what extent he regarded his role as defending the views of Grosseteste vis-à-vis Fishacre's corrections remains a matter of conjecture.

What is noteworthy about Fishacre's extracurricular treatise on the eternal duration of the world is the witness it bears to an active interest and lively debate regarding the subject on the part of the earliest Oxford masters. The Fishacre contribution provides the missing link between the rather less tolerant views of Robert Grosseteste and the rebuttal of Richard Rufus, which was aimed at Fishacre, possibly for his implicit criticism of Grosseteste.

64. Cf. Appendix B, pp. 93-94, n. 12: «Sed isti idem addunt aliquid de subtili quod non verum esse intelligo. Dicunt enim quod 'in primo nunc temporis simul sunt esse et non esse primae creaturae...'».

65. Ibid.

66. Ibid., p. 94 , n. 13.

67. I refer to Fishacre's argument allowing for the possibility of an eternally created world. 
While the Fishacre arguments are not terribly remarkable nor altogether original, they provide further evidence of the brisk exchange of texts between Paris and Oxford and the continued currency of arguments mounted by Maimonides and later by Alexander of Hales and Philip the Chancellor. They also bear witness to a theologian with an extremely subtle mind, who took seriously the scholastic enterprise and contributed to its advance.

\author{
R. James LONG \\ Department of Philosophy \\ Fairfield University, Fairfield \\ Connecticut 06430-7524 USA
}




\section{APPENDIX A}

Fishacre's question De creatione vel inchoatione mundi is edited from London, BL Royal MS 10.B.VII $(=R)$, ff. $386^{\mathrm{rb}}-388^{\mathrm{va}}$, and Paris, Bibliothèque nationale lat. MS $15754(=P)$, ff. $87^{\text {vb }}-89^{\text {va }}$. Although there is no recent catalogue for either library, brief descriptions of the two manuscripts may be found in my "The Science of Theology" (supra, nt. 8), pp. 76-77.

Although $R$ is in general a superior witness, it is not in this text always so, since there is no evidence that $P$ was copied from it. Rather it seems to be the case $R$ and $P$ were copied from a common source. Hence, though my inclination was to follow $R$ when either reading made sense, I allowed the latter finally to dictate my choices.

For ease of access I have not only standardized the orthography but also employed modern punctuation. With respect to paragraph divisions, I normally took my cue from $R$.

\section{$<$ RICHARD FISHACRE, De creatione vel inchoatione mundi>}

IN PRINCIPIO CREAVIT ${ }^{1}$, etc. Huius Scripturae sensus litteralis 1 multiplex est: uno enim modo non exprimitur hic nisi creatio creaturae corporalis; alio $^{\mathrm{a}}$ autem modo exprimitur hic creatio et naturae corporalis et spiritualis. Primo modo sic exponitur 'in principio' (temporis) 'creavit Deus caelum et terram', 'caelum' id est continens omnia infra se corpora, id est supremum corporum - non dico caelum firmamenti, sed caelum superius, scilicet empyreum. Quod enim hic de empyreo intelligendum sit dicunt Hieronymus, Strabus, Beda, Ioannes Damascenus, Basilius, licet Gregorius Nyssenus ${ }^{2}$ et Iosephus ${ }^{3}$ aestiment hoc caelum non esse aliud quam firmamentum secundo die factum.

\footnotetext{
a alio ... corporalis om. $\mathrm{R}$

${ }^{1}$ Cf. 2 Sent., dist. 12, cap. 3.

2 Cf. De hominis opificio 1.1 (ed. ForbesIus, p. 115).

3 Josephus, Ant. iud. 1.1.1 (ed. Blatt, p. 127).
} 
ET TERRAM, "hanc quam calcamus quae terra adhuc inanis, 2 quia nondum germinaverat terrae nascentia; et vacua $a b$ animalibus quae erant eam inhabitura. Et per hoc quod sequitur: 'tenebrae erant super faciem abyssi', insinuat quod totum medium spatium inter caelum et terram, id est supremum corpus et infimum, repleverunt aquae simul factae cum caelo et terra. Quas tamen forte non dicit factas cum caelo et terra, quia illae erant materiales rebus fiendis inter caelum et terram. In principio enim mundi moles, etsi non omnes mundi species, perfecta est. Super abyssum itaque aquarum mediarum erant tenebrae, quia nondum erat lux tenebras earum illustrans et spiritus Domini, id est bona voluntas eius, ferebatur super has aquas per intentionem educendi eas in species visibiles. Quod ut fieret, verbo Deo primo de his aquis facta est lux corporalis, aquarum dictas tenebras usque ad terram illustrans, et spatium diurnum, scilicet 24 horarum aequinoctialium sic dividens ut in earum medietate terrae habitationem illustraret et in altera medietate eiusdem lucem subduceret, et sic fecit diem et noctem, quae sunt unus dies naturalis» ${ }^{4}$.

Hoc sic «crediderunt Beda, Ambrosius, Iosephus, Hieronymus, et Basilius. Vel nomine caeli et terrae possunt comprehendi et omnia creanda deinde per partes explicanda. Vel per caelum etc.: intelligitur forma prima et materia prima; his igitur tribus modis tantum corporalium creatio exprimitur» 5 .

Sunt et alii modi quibus omnis creaturae tam spiritualis quam corporalis creatio exprimitur et secundum hoc hic exponit Magister, ut per 'caelum' spiritualis creatura, per 'terram' corporalis intelligatur et utraque adhuc imperfecta et informis.

«Vel per caelum intelligatur spiritualis creatura perfecta et beata 5 per terram vero corporalis materia adhuc imperfecta cuius informitatem insinuat subiungens: 'Terra autem erat inanis et vacua'” $<$ Gen. $1,2>^{6}$.

Quia vero nomen «principii» materialiter dicitur, ut intelliga- 6 mus quomodo hic ${ }^{\mathrm{b}}$ accipitur, sciendum quod dicitur "primum» in

\footnotetext{
b om. P
}

\footnotetext{
${ }^{4}$ Robert Grosseteste, Hexaemeron 1.7 (edd. Dales / Gieben, pp. 56-57).

5 Ibid. 12.1 (edd. Dales / Gieben, p. 68).

${ }^{6}$ Ibid.
} 
unoquoque genere ante quod non est aliud illius generis. Sic dicitur "principium in tempore» et "principium in numero» et «in magnitudine» et «in motione»: et hoc modo sumptum non privat "esse aliud ante» sed privat «aliud eiusdem generis praecesisse»; similiter dicitur "principium» ars artificii, et finis dicitur "principium eorum quae sunt ad finem» et "principium movens» ut res sit, et ${ }^{c}$ sic "principium» dicitur. Omnes autem hi modi in intellectu huius distinctionis "principium» hic coacervantur. Sed si tribus ultimis modis intelligatur, ponitur «in» pro «per»: Deus enim «in» principio, id est "per» principium, id est per se ipsum, qui est primus movens et ultimus finis omnium secundum illud ${ }^{\mathrm{d}}<\operatorname{Prov}$. 16,4>: 'Omnia propter semetipsum operatus est Dominus'; et $I s .{ }^{\text {e }}<41,4>$ : 'Ego primus et ego novissimus sum'.

Qui etiam est sua ars et sua sapientia per quam fecit omnia secundum illud Ps. $<103,84>$ : 'Omnia in sapientia fecisti'

Secundum autem quod dicit "principium temporis» tripliciter 8 intelligi potest, quia principium in tempore est tripliciter: vel primum instans temporis, vel primum modicum tempus anterius terminatum ad instans indivisibile primum, vel species temporis, a qua incepit tempus, ut ver vel primus mensis, $i^{f}$ est primi mensis initium. 'In principio' ergo temporis, scilicet in vere et non in toto vere sed 'in principio', id est in prima parte veris, quae utique tempus est, immo et 'in principio', id est in primo instanti illius primae partis veris, 'creavit caelum et terram', scilicet vel creaturam corporalem et spiritualem, vel primam materiam et ${ }^{\mathrm{g}}$ primam formam, vel supremum corpus et infimum et aquas vaporabiles medias. «Moles enim et magnitudo eorum, quae cernuntur per omnes auctoritates, exstructa est ${ }^{8}$, sed in proprias species distincta secundum Augustinum?

c et sic om. R

d spatium $\mathrm{P}$; crux $\mathrm{R}$

e spatium $\mathrm{P}$

$f$ id est primi mensis om. R

$\mathrm{g}$ et primam formam om. R

7 Cf. ibid. 1.10.1 (edd. Dales / Gieben, pp. 64-65).

${ }^{8}$ Cf. ibid. (edd. Dales / Gieben, p. 65).

${ }^{9}$ Cf. Augustinus, De Genesi ad litteram 1.9 (CSEL 28.1,13). 
Facta est ergo moles et magnitudo universi in primo instanti primi mensis primi temporis, scilicet veris, qui mensis est $\mathrm{Nisan}^{\mathrm{h}}$, de quo Ex. $12<2>$ : 'Mensis iste vobis principium mensium, primus erit in mensibus anni', scilicet in aequinoctio vernali ${ }^{10}$. Et merito quaeritur quare magis creatum sit universum in aequinoctio quam in solstitio vel alio tempore. Item, si debuit creari in aequinoctio, quare magis in vernali quam in autumnali?

Ad primum dico quod merito primus dies mundi - immo, ut verius dicatur, dies anniversarius creationis mundi vel natalicius est primus dies veris vel primus dies Nisan vel aequinoctialis, quia hic dies omnem alium diem anni: scilicet duo dies aequinoctiales in hoc excellunt quod in die aequinoctiali tota terrae superficies, scilicet quilibet punctus in superficie terrae, illuminatur. Quippe in tali die sol describit aequinoctialem, et ideo in quolibet momento diei aequinoctialis radius solaris contingit ad utrumque polum, scilicet australem et septentrionalem; in quolibet autem alio die praeterquam in duobus aequinoctialibus aliqua pars terrae necessario est quae per totum diem naturalem est non illuminata. Et ideo omnes alii dies quasi particulares et imperfecti dies sunt, et aequinoctialis dies est perfectus et universalis.

Ad secundum dico quod primus dies mundi, id est anniversarius dies eius vel natalicius, est dies aequinoctialis vernalis potius quam dies aequinoctialis autumnalis, quia in aequinoctio autumnali est recessus solis ab habitabili parte terrae, et per consequens tempus illud est non generationis et perfectus inferiorum, sed potius corruptionis et defectus. $\mathrm{Si}$ igitur innovatio quaedam universi fit quolibet anno in aequinoctio propter accessionem ${ }^{\mathrm{i}}$ solis ad habitabilem nostram, si mundus fuisset factus in aequinoctio autumnali, tunc ad iteratam eius innovationem non esset nisi dimidius annus, scilicet usque ad vernale aequinoctium, et deinde semper inter innovationes ${ }^{j}$ eius esset annus. Et sic tales innovationes mundi non haberent uniformitatem — quod non deceret.

Item, cum dextrum in caelo sit caput arietis, scilicet punctus aequinoctialis vernalis, sinistrum vero eius sit punctus aequinoctialis

\footnotetext{
h crux $\mathrm{R}$

i tensionem R

j innovationem $\mathrm{P}$
}

10 Cf. Robert Grosseteste, Hexaemeron 1.10.1 (edd. Dales / Gieben, p. 65). 
autumnalis, scilicet caput librae - naturaliter autem omne quod movetur incipit moveri a dextro in sinistrum - naturaliter decuit solem in capite arietis creari et inde incipere motum suum. Sed ${ }^{\mathrm{k}}$ econtrario ponunt astrologi moveri planetas a sinistro in dextrum quod non est verum secundum opinionem naturalium.

Sed ${ }^{1}$ ut dicit tantae Scripturae auctoritas: 'In principio fecit Deus universum'. Hic merito opiniones philosophorum ponentium contrarium huic Scripturae sanctissimae et verissimae pertractentur. Et primo dicemus opiniones, deinde earum rationes, tertio ad easdem pro parvitate $\mathrm{mea}^{\mathrm{m}}$ responsiones, quarto contra eorum opinionem inducentur rationes.

De primo legimus multos philosophorum credidisse mundum aeternum, carentem principio et fine, et Deo coaeternum. De his fuerunt Aristoteles, Plato, Apuleius, Plinius. Quod autem hoc voluit Aristoteles patet plane ex littera eiusdem in 8 Physicorum et ex mediis inductis ad conclusionem suam ibidem et ex ultima sui libri conclusione, quam intendit probare de motore primo per motus perpetuitatem ${ }^{11}$. Probat enim ibi et similiter in XI Metaph. ${ }^{12}$ motoris aeternitatem per aeternitatem motus. "Expositores etiam eiusdem loci Aristotelis, tam Graeci quam Arabes, dictum locum de perpetuitate, id est duratione infinita ex utraque parte temporis motus et mundi, concorditer exponunt. Boethius quoque in libro De consolatione evidenter asserit tam Aristotelem quam Platonem sensisse mundum initio caruisse» ${ }^{13}$. Haec idcirco dixerimus, quia nonnulli modernorum hoc Aristotelem noluisse asserunt, quasi melius eum intelligerent et verius interpretentur "ex littera latina satis corrupta quam philosophi, tam gentiles quam Catholici, qui eius Scripturam incorruptam et ${ }^{\mathrm{n}}$ originalem, scilicet graecam, plenissime noverunt», nolentes aliquo modo concedere ipsum haereticum fuisse ${ }^{14}$. Cum tamen de Aristotele dicat Augustinus De civitate Dei, lib. 8: «Aristoteles, Platonis

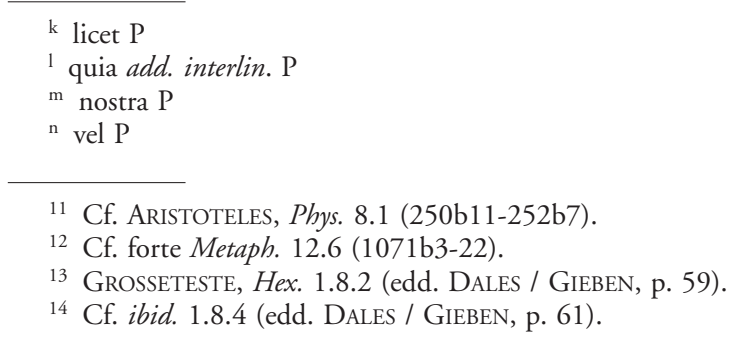


discipulus, vir excellentis ingenii et eloquio quidem Platoni impar, sed multo facile superans, sectam Peripateticam condidit, quod deambulans disputare consueverat, plurimos discipulos praeclara fama excellens vivo adhuc praeceptore in suam haeresim congregavit» ${ }^{15}$.

Item $^{\circ}$, Ambrosius in Hexaemeron: "Ipsum mundum semper fuisse et fore Aristoteles usurpat dicere de Platone insuper quod voluerit mundum esse coaeternum Deo» ${ }^{16}$. Dicit Augustinus De civitate Dei, lib. 10 et insuper in 13 lib. «refert Platonem sensisse mundum esse animal beatissimum, maximum et sempiternum» ${ }^{17}$. De Apuleio refert ${ }^{\mathrm{P}}$ Augustinus De civitate Dei lib. 12: Ipsum «cum multis aliis credidisse mundum et hominem semper fuisse» ${ }^{18}$. "Plinius vero libro secundo De naturali historia dicit mundum numen esse aeternum et immensum, neque genitum ${ }^{q}$ neque interiturum umquam ${ }^{19}$.

Sed sciendum licet posuerunt omnes dicti et multi alii philosophorum mundum coaeternum Deo, tamen diversimode. Quidam enim ita eum Deo coaeternum posuerunt, ut omnino ab alio non esset et ideo neque creatus esset, de quibus legimus ${ }^{\mathrm{r}}$ lib. De civitate Dei 11; de quibus ibi dicit Augustinus quod "nimis aversi sunt a veritate et letali impietatis morbo insanientes» ${ }^{20}$. Quidam vero ita ponunt ${ }^{\mathrm{s}}$ mundum coaeternum Deo, ut tamen a Deo sit et factus sit. Sed adhuc dupliciter. Quidam enim ponunt ipsum esse a Deo ipso invito, de quibus legimus in Hexaemeron Basilii, homelia prima, dicentis: "Quamvis Deum mundi fateantur auctorem esse, ita tamen fatentur

\footnotetext{
o item ... dicere transpos. post sempiternum $\mathrm{R}$

$\mathrm{p}$ dicit $\mathrm{P}$

$\mathrm{q}$ ingenitum $\mathrm{P}$

${ }^{r}$ legitur $\mathrm{P}$

$s$ posuerunt $\mathrm{P}$
}

\footnotetext{
15 Augustinus, De civitate Dei 8.12 (CCL 47, 229).

${ }^{16}$ Ambrosius, Hexaemeron 1.1.3 (CSEL 32.1,4); citata ex Grosseteste, Hex. 1.8.3 (edd. Dales / Gieben, p. 60).

${ }^{17}$ Augustinus, De civitate Dei 10.29 (CCL 47,306) et 13.16 (CCL 48,357); citata ex GROSSETESTE, ibid.

18 Ibid. 12.10 (CCL 48,364-65); citata ex GROSSETESTE, ibid.

19 Plinius, Nat. hist. 2.1.1.1 (ed. Sillig, 1, 101); citata ex Grosseteste, ibid.

20 Augustinus, De civitate Dei 11.4 (CCL 48, 23); citata ex Grosseteste, Hex. 1.8.2 (edd. Dales / Gieben, p. 59).
} 
ut sine voluntate ipsius processisse confirment, sicut ex corpore umbram velt ex luce fulgorem ${ }^{21}$. Quidam vero ponunt mundum a Deo factum sed per eius voluntatem cum Deo coaeternum, sicut si $\mathrm{ab}$ aeterno fuisset pes in pulvere, $\mathrm{ab}$ aeterno et coaeternum pedi esset vestigium; et tamen vestigium fuisset a pede. Unde Augustinus De civitate Dei. lib. 10 in fine ${ }^{22}$.

Rationes autem quibus innituntur ponentes mundum aeternum sunt plures. Prima ratio: dicit ${ }^{\mathrm{u}}$ Augustinus De doctrina Christiana lib. 1, et ponitur in distinctione prima primi libri Sent." : "Quia Deus bonus est sumus» ${ }^{23}$. Sed ab aeterno bonus est. Ergo ab aeterno sumus, quia posita sufficienti causa vel antecedente ponitur effectus vel consequens ${ }^{24}$.

Item, sic arguit Augustinus volens ostendere Filium esse coaeternum Patri et coaequalem in libro Contra Maximinum Haereticum ${ }^{25}$, et ponitur primo libro dist. 2026: Deus Pater aut potuit aut non potuit generare aequalem sibi Filium ${ }^{w}$. Si non potuit, impotens fuit; si potuit aut noluit, et tunc invidus ${ }^{\mathrm{x}}$ fuit. Aut voluit et tunc ${ }^{\mathrm{y}}$ fecit. Similiter cum aeternum sit melius non-aeterno, aut potuit creasse mundum sibi coaeternum aut non. Si non, impotens fuit; si sic, aut noluit - et tunc invidus ${ }^{2}$ fuit - aut voluit et tunc fecit.

Item, sufficienti agente existente statim agit, ut sit actum; sed sufficientem agentem tria constituunt, scilicet potentia, sapientia, et voluntas. Igitur quam cito aliquis agens habet potentiam, sapientiam, et voluntatem, statim agit et movet, ut sit actum. Cum igitur Deus
${ }^{t}$ et $\mathrm{P}$
u om. P
v om. R
w del. P
$\mathrm{x}$ mundus $\mathrm{P}$
${ }^{\mathrm{y}}$ si potuit et voluit add. $\mathrm{P}$
z invidus fuit: mundus $\mathrm{R}$

21 Basilius, Hex. 1.2.1 - 1.3 .8 (edd. E. Amand de Mendieta et S.Y. Rudberg, pp. 5-6); citata ex Grosseteste, Hex. 1.8.3 (edd. Dales / Gieben, p. 60).

22 Augustinus, De civitate Dei 10.31 (CCL 47,309); citata ex Grosseteste, ibid.

23 Augustinus, De doct. Christ. 1.32 (CCL 32,25); 1 Sent. 1.3 (p. 59).

24 Cf. Alexander de Hales, De duratione mundi, in: Donald M. NATHanson (ed.), Alexandri de Hales 'De eternitate, evo, et tempore' et 'De duratione mundi', diss. University of Southern California 1986, p. 69.

25 Augustinus, Contra Maximinum 2.12-18 (PL 42, 766-87).

26 Petrus Lombardus, Sent. 1.20 .3 (1:173). 
sit non tantum agens sufficiens, immo sufficientissimus, eo quod non habet tantum potentiam, sapientiam, et voluntatem, sed potius omnipotentiam, omniscientiam ${ }^{\text {aa }}$, et summam voluntatem, statim cum est, agit, ut actum sit. Sed virtus infinita subito agit actum finitum. Igitur si agens iste virtutis infinitae est aeternus, sic et actum eius sit ${ }^{\mathrm{bb}}$ ei coaeternum.

Item, ut dicit Aristoteles in 2 Metaph.: Actio primi est sua substantia ${ }^{27}$. Et hoc necesse est si est simplex. Sed substantia primi est aeterna. Ergo et actio. Sed ut dicit ibidem Aristoteles: Actio primi est quod movet sine movere ${ }^{28}$. Ergo ab aeterno movet. Ergo ab aeterno est motus et mobile etiam ${ }^{29}$.

Item, virtus argumenti positi in 8 Physic. sic potest extrahi. Si incepit esse motus cum prius non fuit, incepit esse motor cum prius non fuit motor. Sed constat: sua substantia non incepit esse. Ergo cum prius fuerit sua ${ }^{\mathrm{cc}}$ substantia non movens, deinde movens, mutationem passus est, et sic non est motor primus. Sed hoc est impossibile. Ergo primum ${ }^{30}$.

Item, si idem manens omnino idem non est natum facere nisi semper idem $^{31}$, qua ratione Deus, semper manens semper ${ }^{\text {dd }}$ idem secundum illud $P_{S .}<101,28>$ : 'Tu autem idem ipse es', nunc crearet mundum eadem ratione et prius? Et adhuc illo priori prius. Et sic aut numquam creasset mundum aut ab aeterno creavit. Qua enim ratione nunc crearet mundum magis quam prius, quis dicere potest? Ex parte enim ipsius non est ratio aliqua quare nunc et non prius, cum omnino similiter se habuerint et nunc et prius; neque in re facienda, quia nihil fuit ipsa.

Item, in omni habente initium verum est non fuisse, quia non-esse in eis praecessit esse. Igitur si est primum instans temporis vel mundi,

a om. R

bb est $\mathrm{P}$

cc om. R

dd om. P

${ }^{27}$ Forte ARISTOTELES, Metaph. 12.7 (1072b25-30).

${ }^{28}$ Forte ibid., 12.6 (1071b3-12). Cf. Phys. 8.6 (258b10-17).

${ }^{29}$ Cf. Alexander, De duratione mundi (ed. Nathanson, p. 76).

30 Cf. ARIstoteles, Phys. 8.1 (251b29-252a4).

31 Cf. ARISTOTELES, De gen. et corr. 2.10 (336a27-28); cf. J. HAMESSE, Les Auctoritates Aristotelis, Louvain 1974, p. 170, n. 43. 
in illo instanti quod vocetur $a$ verum fuit mundum esse. Et verum fuit mundum non-esse, aut ergo in eodem instanti aut in alio. Si in eodem instanti, probatio quod hoc esse non potest. Affirmatio enim ${ }^{\text {ee }}$ et negatio, quae sunt termini generationis, minus distant quam quae sunt termini creationis. Prima enim commune habent, saltem materiam; secunda vero nihil omnino, quia creatio est ex nihilo. Cum igitur esse et non-esse quae sunt termini generationis in eodem instanti simul esse non possunt, multo magis nec esse et non-esse quae sunt termini creationis in eodem instanti simul vera esse potuerunt. Igitur utrumque horum, scilicet mundum esse et non esse, non sunt vera in primo instanti. Igitur non-esse verum in alio instanti praecedente primum instans, et inter haec, sicuff ${ }^{\mathrm{ff}}$ inter quaelibet duo instantia, est tempus medium. Ergo ante primum instans temporis est tempus. Ergo ab aeterno ${ }^{32}$.

Cui videtur similiter Augustinus cum Apostolo consentire De civitate Dei lib. 2, cap. 14: "Quae saeculi praeterierint antequam genus constitueretur humanum, me fateor ignorare. Dicit enim Apostolus tempora aeterna, nec ea esse futura, sed quod magis mirandum praeterita. Sic enim ait: 'In spem vitae aeternae, quam promisit non mendax Deus ante tempora saecularia' ${ }^{33}$, ut patet I Tit. $1<2>$ et simile II Tim. primo $<9>$ : Gratia 'quae data est nobis ante tempora saecularia in Christo Iesu'. Et ${ }^{\mathrm{gg} g}$ per hoc innuit Apostolus esse aliqua tempora quae praecedant tempora saecularia; sed et alibi secundum litteram nostram tempus esse aeternum vel ${ }^{\text {hh }}$ praeteritum legimus. Ro. $16<25>$ : 'Potens est vos confirmare iuxta evangelium meum ... secundum revelationem mysterii temporibus aeternis taciti'. Ps. $<76,6>$ : 'Annos aeternos in mente habui'. Bar. $3<32>$ : Et 'separavit terram in aeterno tempore'ii.

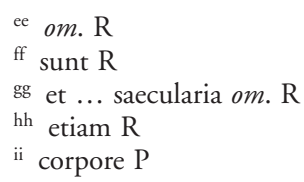

32 Verbotenus in: Richardus Rufus, In 2 Sent. 1.1 (ed. Brown, p. 273). The reply (see below) is also to be found in Rufus' Commentary with only minor changes. The argument reappears in an anonymous question by a Franciscan master, written between 1274 and 1277; cf. Richard C. Dales et Omar Argerami (edd.), Medieval Latin Texts on the Eternity of the World, Leiden 1991, pp. 100, 108-109.

33 Augustinus, De civitate Dei 12.17 (CCL 48,373). 
Deut. $33<15>$ : 'De pomis collium aeternorum'. Sed non prius fuerunt colles quam mundus vel tempus.

Solutio. Ad primum dicendum: confiteor Dei bonitatem esse sufficientem causam esse nostri; ipsa nimirum est sapientissima et omnipotens voluntas Dei. Sed duplex est causa vel principium rei. Est enim causa vel principium naturale et voluntarium. Principium naturale est agens impetuosum, sed voluntarium est considerosum. Et ideo posita causa sufficiente naturali ponitur statim actio. Sed non sic causa posita sufficiente voluntaria ponitur actio necessario. Quippe quascumque voluntati addideris condiciones, semper est contingentia, non necessitas respectu actionis propriaeji. Quippe semper est voluntas. Et ideo semper valet ad opposita, scilicet ad agere et non agere. Cum ergo dicitur "quia bonus est sumus», ly "quia» non dicit «consequentiam» sed "causam» — et hoc non quamlibet, quia non naturalem sed voluntariam, eo quod bonitas voluntas in Deo est. Ratione autem iam dicta non sequitur neque oportet quod posita sufficienti causa voluntaria ponatur causatum. Et ideo non sequitur, licet talis sufficiens causa sit aeterna, quod causatum sit similiter aeternum.

Ad secundum dico quod Deus non potuit creare mundum vel creaturam aliquam sibi coaeternam nec tamen impotens fuit. Immo si posset, creatura ei erit coaeterna, iam potius impotens esset. Impotentiae enim in eo aliquid est, si non est tam potens ut creatura ei non possit ${ }^{\mathrm{kk}}$ aequari. Nec ${ }^{\mathrm{ll}}$ est simile de Filio. Si enim crearet creaturam ex se ipso, impotens esset; si non, aequalem sibi crearet. Quippe non potest esse defectus. Quare factum factori non sit aequale, nisi aut ex parte agentis vel eius ex quo sit. Sed si de ipso creaturam faceret, sicut de sua propria substantia Filium gignit, iam in eo ex quo fit non est defectus. Igitur si factum factori non est aequale, erit defectus et impotentia in ipso agente. Nunc autem quia creaturas non de se ipso sed de materia vel nihilo facit, quare creatura deficit a creatore, ut non sit ei coaeterna vel coaequalis, sicut est Filius Patri. Causa est impotentia non agentis sed potius eius ex quo fit ${ }^{34}$.

\footnotetext{
ji om. R

${ }^{\mathrm{kk}}$ posset $\mathrm{R}$; corr. ex posset $\mathrm{P}$

ll et hoc non $\mathrm{P}$
}

34 Cf. AleXander, De duratione mundi (ed. NATHAnson, pp. 68-69). 
Ad tertium iam patet ex dictis ad primum quod, licet Deus sit sufficientissimus agens et infinitae potentiae, non tamen est suum sibi coaeternum, quia est causa voluntaria, non naturalis, et ideo non necessario coexistit ei suum actum, sicut supra dictum est.

Scimus tamen quosdam magnae auctoritatis quidem quorum scientia confortata est in tantum ut non possim ad eam (aliter ad dicta) respondere sic. Dicunt quod sufficiens causa et causatum simul sunt in tali causa et causato, quae sunt eiusdem mensurae ut quorum utrumque temporale vel utrumque aeternum. Unde cum secundum Iohannem Chrysostomum et Damascenum ${ }^{35}$, Pater sit causa sufficiens Filii, et utriusque est eadem ${ }^{\mathrm{mm}}$ mensura, scilicet aeternitas, necessario simul sunt. Sed in his in quibus causa et causatum sunt diversarum mensurarum, ut unum aeternum et alterum temporale, non est necesse simul esse ${ }^{36}$.

Sed vellem ab eis doceri. Non enim intelligo si iam sufficit haec eorum responsio, cum causa temporalis possit facere suum actum vel motum esse simul secum tempore. Si dico sit sufficiens causa, quare non similiter causa aeterna sufficiens possit facere suum actum sibi coaeternum, cum causa aeterna in infinitum sit potentior causa temporali?

Ad quartum dupliciter dicitur "prius» secundum eius famosas species, scilicet prius natura et prius tempore. Sed cum sit Deus prius creaturis aeternitate, patet quod ly $\mathrm{y}^{\mathrm{nn}}$ "prius» non reducetur ad prius tempore, sed potius ad ${ }^{\text {oo }}$ prius natura; et erit prius aeternitate, sicut quaedam species prioris natura. Unde Boethius in libro De consolatione

$\mathrm{mm}$ causa $\mathrm{R}$

nn hoc R

oo ly $\mathrm{P}$

35 Cf. Johannes Chrysostomus, In epis. ad Hebr., hom. 2, n. 2 (PG 63, 21); et Johannes Damascenus, De fide orthod. 8.2 (ed. Buytaert, p. 30).

36 Cf. Robert Grosseteste, Hex. 1.8.6 (edd. Dales / Gieben, p. 62). Cf. also Grosseteste, De finitate motus et temporis 2 (ed. Richard C. Dales, "Robert Grosseteste's Treatise 'De finitate motus et temporis'”, in: Traditio 19 (1963), pp. 260-261. According to Prof. Dales (private correspondence) Fishacre's reference to the De finitate here would not only be a first but possibly only use of that work by a thirteenthcentury master. Dales in his search of thirteenth- and fourteenth-century writers had failed to find any other evidence of the knowledge of this treatise (p. 251). It would also show, according to Dales, that the De finitate was known as a separate work by 1248 at the latest. 
philosophiae: Deus non est creaturis antiquior tempore sed simplicitate naturae ${ }^{\mathrm{p} 337}$. Et dico quod prius aeternitate est species prioris natura, non idem penitus, quia prius aeternitate aliquid superaddit priori ${ }^{99}$ naturae, quia sequitur: est prius aeternitate; ergo est prius natura, et non econtrario. Quaelibet enim causa temporalis est prior natura suo effectu, nec tamen prior aeternitate.

Hinc patet quod hoc argumentum non valet: simul sunt movere et moveri; $\mathrm{ab}$ aeterno movet vel est motor; ergo ab aeterno est motus vel mobile. Scimus enim quod prius natura est motor et movere quam mobile vel moveri quod est motum esse. "Passio enim est effectus illatioque actionis", ut dicitur in Sex principiiis ${ }^{38}$. Effectus autem posterior est natura quam causa. Quamvis igitur simul tempore sicut movere et moveri sunt, non tamen simul natura. Cum igitur dicitur «movere et moveri sunt simul», ly «simul» dicit simultatem secundum tempus, si debet esse vera, et ita dicit "tempus». Sed cum assumit quod movere est ab aeterno, cum esse ab aeterno sit, esse primum natura est. Ac si sic argueretur: movere et moveri sunt simul tempore; sed movere est primum natura; ergo ${ }^{\text {rr }}$ moveri est primum natura, constat quod non sequitur. Sed si in prima propositione diceretur "simul natura», bene sequeretur. Ergo prima existente falsa tenet argumentum. Sed secundum quod vera est non tenet.

Ad quintum iam patet ex ultimo dictis quod non sequitur: motus incepit esse, ergo motor incepit ${ }^{\text {ss }}$ esse motor. Motor enim, ut dictum est, $\mathrm{ab}$ aeterno fuit motor et movens. Neque tamen ab aeterno fuit motus. Sed habuit initium motus. Ergo incepit esse, quia non fuit primum natura. Sed motor vel movere non incepit esse sed fuit primum natura.

Neque sequitur Deum esse mutabilem; non enim concedemus quod de non-agente factus sit agens, cum ab aeterno fuerit agens, sed

Pp om. R

qq prioritati $\mathrm{P}$

${ }^{\text {rr }}$ ergo ... natura om. R

ss incipit $\mathrm{P}$

37 Boethius, De consolatione philosophiae 5, pr. 6 (CCL 94, 101sq.).

38 Gilbertus Porretanus, Liber de sex principiis 3.10, in: L. Minio-Paluello (ed.), Categoriarum supplementa (Aristoteles Latinus. Corpus philosophorum medii aevi I, 6-7), Bruges 1966, p. 15,10; proxime J. HAMESSE, Les Auctoritates (supra, nt. 31), p. 307, no. 11 . 
potius de non-agente hoc. Factus est agens hoc, non quia aliqua mutatio facta sit in ipso, sed in acto: sicut sol potest fieri de nonlucente super hoc, lucens super hoc sine aliqua mutatione solis per mutationem rei illuminatae.

Verumtamen quicquid dicat Aristoteles, aestimo quod per se «actio primi» non est movere neque aliqua actio respectu creaturae. Sua enim actio per se absoluta est ab omni creatura, scilicet intelligere, sicut sua substantia.

Sed significat movere actionem eandem ei propriam, scilicet intelligere, cum superadditione comparationis ad creaturam, sicut lucere et illuminare significant eandem actionem solis; sed lucere significat eam respectu agentis tantum; illuminare vero superaddit respectum ad aliquid aliud in quo est actio. Unde sicut sol posset incipere illuminare nec tamen incipere lucere — et hoc non per suam sed rei illuminatae mutationem - sic Deus incepit esse movens et movere sine sui mutatione per mutationem mobilis. Neque tamen incepit intelligere neque novo sed aeterno consilio fecit omnia quae temporaliter facta sunt. Unde Augustinus, De civitate Dei lib. 12, cap. 15: "Potest autem Deus ad opus novum non novum, sed sempiternum adhibere consilium ${ }^{39}$.

Ad sextum: quare ${ }^{\text {tt }}$ tunc creavit mundum et non ante? Ad hanc quaestionem dupliciter responderi potest. Uno modo sicut respondetur ad hanc: quare nunc creavit hanc animam et non prius? Ad utramque enim respondetur quod creavit tunc mundum et non prius, et ${ }^{\mathrm{uu}}$ nunc hanc animam et non prius, quia sic fuit optimum fieri. Quare autem fuit optimum sic ${ }^{\text {vv }}$ fieri, dico quia Deus voluit; ita enim est de voluntate eius quod non ideo vult aliquid fieri, quia optimum est fieri, sicut nos, sed potius econtrario: quia vultww ${ }^{\text {ww }}$ est optimum. Si autem quaeritur quare vult illud optimum, quaeritur medium propositionis immediatae. Et ita nihil quaeritur. Potest etiam aliter dici ad propositionem quod haec quaestio, "quare fecit mundum nunc non prius», fundatur super falsam quandam imaginationem, qua imaginatur

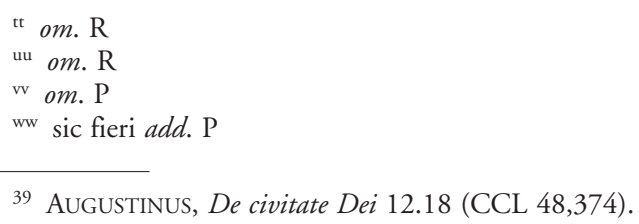


fuisse ante mundum tempus. "Ante» enim "tempus» dicit; et quare tam tarde fecerit mundum in illo tempore quaeritur, sicut imaginationes infinitum locum extra mundum quaerere possent ${ }^{\mathrm{xx}}$, quare magis hic fecit mundum quam alibi? Nunc autem sicut nec extra mundum est locus, sic nec ante mundum fuit tempus, quia ante mundum non fuit mutatio, et ideo nec tempus. Dicit enim Augustinus, De civitate Dei lib. 11, cap. 7: «Quis non videat, quod tempora non fuissent, nisi creatura fuisset, quae aliqua mutatione mutaret» ${ }^{40}$.

Ad septimum notandum ${ }^{y y}$ quod cum alia verba consignificent ${ }^{2 z}$ tempus ${ }^{41}$, hoc verbum "est» non consignificat tempus, sed potius nunc communiter ad nunc aeternitatis et nunc temporis ${ }^{42}$. Nisi enim diceret nunc temporis, haec esset falsa: «homo est». Nisi autem diceret nunc aeternitatis, falsa esset haec: "Deus est", et non dixisset Deus, Ex. $3^{\text {a }}<14>$ : 'Ego sum qui sum'.

Dicamus ergo et concedamus in omni creato non-esse praecedere esse. Sed ${ }^{\mathrm{b}}$ in quibusdam non-esse praecedit esse in tempore, ut in animabus quae nunc creantur. In quibusdam vero non-esse praecedit esse $e^{c}$ tantum natura, et hoc est in primis creaturis de quibus agimus nunc ${ }^{43}$.

Sciamus ergo quod in illis, cum dico "prius non-esse quam esse», 39 non affirmatur esse et negatur respectu eiusdem mensurae. Sed esse negatum dicit nunc aeternitatis, esse affirmatum nunc temporis primum $^{44}$. Cum igitur $<$ hoc $>$ sit, quaeritur de prima creatura in primo nunc temporis: fuit verum esse, fuit et verum non-esse. Aut ergo in eodem nunc aut in alio. Respondeo: «et» in eodem nunc ${ }^{\mathrm{d}}$ "et» in alio. Sed in alio quidem non eiusdem generis, scilicet in nunc aeternitatis, quod aliud a nunc temporis est.

xx possunt $\mathrm{P}$

yy nota $\mathrm{P}$

zz significent $\mathrm{R}$

a spatium $\mathrm{R}$

b sed ... tempore om. R

c om. P

d om. R

40 Ibid. 11.6 (CCL 48,326).

41 Cf. ARISTOTELES, De interpretatione 1.5.

42 Cf. Petrus Lombardus, 1 Sent. 44.2.1-4.

43 Verbotenus in: Richardus Rufus, In 2 Sent. 1.1 (ed. Brown, p. 273).

44 Ibid. 
Sed cum procedit, dicens: «sed inter quaelibet duo nunc est 40 tempus medium ${ }^{45}$, hoc verum ${ }^{e}$ est de duobus nunc eiusdem generis, ut de duobus nunc temporis. Sed hoc falsum est de nunc aeternitatis et nunc temporis, quia inter haec nihil est medium, cum nunc aeternitatis sit cum quolibet nunc temporis totum, sicut anima cum qualibet parte sui corporis tota.

Dixi insuper, et ut aestimo verum dixi, quod «in eodem nunc simul sunt», scilicet in primo nunc temporis esse et non-esse primae creaturae, et generaliter in omnibus creatis de nihilo, cum non-esse praecedat esse secundum naturam, tamen simul, id est in eodem instanti, sunt temporis. Quod sic patet.

Scimus quod non-esse, cum sit pura negatio, de se nullam quaerit mensuram; esse vero quaerit mensuram. Igitur si esse et non-esse quaerant distinctionem secundum tempus ${ }^{\mathrm{f}}$, hoc non erit, nisi quia illud non-esse habet in se aliquod esse aliud ab esse negato ${ }^{46}$. Igitur ubi ita est quod esse et non-esse habent esse et esse diversum, ut est in illis esse et non-esse, quae sunt generationis extrema, patet quod illa esse et non-esse necessario habent distinctionem secundum tempus. Et non sunt in eodem nunc temporis. Sed in talibus esse et non-esse quae non habent esse et esse, sed tantum esse et simpliciter non-esse, ut est in illis quae sunt extrema creationis, necessario non quaerent illa esse et nonesse distinctionem secundum tempus, sed compatiuntur se in eodem nunc temporis in quo se habent per prius et posterius natura. Igitur in primo instanti temporis verum fuit primam esse creaturam et non-esse; prius tamen natura non-esse quam esse, sicut eadem lux in eodem nunc temporis est in oriente et occidente, tamen prius natura in oriente.

Quod autem obicitur quod plus distant esse et non-esse, quae sunt extrema creationis, quam quae sunt extrema generationis, sic solvitur. Licet extrema generationis minus distent, tamen non se compatiuntur in eodem nunc temporis, quia sunt causa diversorum nunc temporis. Diversum enim esse est causa diversi nunc temporis. In non-esse autem quod est unum extremum generationis est esse diversum $a b$ eo esse quod est alterum generationis extremum. Sed

\footnotetext{
e om. P

f et esse add. P

45 Ibid.

46 Ibid. (ed. BROWN, pp. 273-274).
} 
extrema $^{g}$ creationis, scilicet esse et non-esse, bene compatiuntur se in eodem nunc temporis, quia, ut dictum est, non sunt aliquo modo causa diversorum nunc; in non-esse enim quod est extremum creationis non est esse. Sed ${ }^{\mathrm{h}}$ nota quod sicut ${ }^{\mathrm{i}}$ esse creatum necessario requirit instans temporis', sic non-esse praecedens creationem eo quod pure nihil est necessario requirit ut non mensuretur instanti.

Ad octavum, scilicet $\mathrm{ad}^{\mathrm{k}}$ auctoritatem, dicendum quod hoc totum ante aeterna tempora circumlocutio est aeternitatis. Unde super illud II Tim. $1<9>$ : 'Ante tempora saecularia ${ }^{\mathrm{l}}$, nihil' ${ }^{\mathrm{m}}$ nos habemus ante tempora saecularia dicit Chrysostomus: Hoc est anarchos, id est sine principio $^{47}$. Et hoc similiter patet ex Augustino De 83 quaestionibus, q. 72, ubi patet quod "eterna tempora" ponitur pro "omnia tempora» et etiam pro «initio temporis», quod non fuit tempus necessario; et ita «ante tempora aeterna» idem est quod ab aeterno. Dicit enim sic: "Quaeri potest, quomodo ab Apostolo Paulo est dictum 'ante tempora aeterna'. Si enim tempora, quomodo aeterna? Nisi forte ante omnia tempora intelligi voluit ${ }^{\mathrm{n}}$, quia si dixisset tempora nec addidisset aeterna, posset accipi ante quaedam tempora, quae ante se haberent alia tempora. Aeterna maluit dicere quam omnia fortasse, quia tempus non coepit ex tempore. Ante aeterna tempora aevum significavit, inter quod et tempus hoc distat, quod illud stabile est, tempus autem mutabile» ${ }^{48}$. Et eadem ratione cum dicitur «aeternis temporibus» vel «aeterno tempore» intelligi potest, id est in omnibus temporibus; similiter possent dici "colles aeterni ${ }^{49}$, id est omnium temporum.

Restat iam ultimo, ut conemur ${ }^{\mathrm{o}}$, si quomodo possimus ${ }^{\mathrm{p}}$, rationibus contra ponentes mundum aeternum agere. Prima ratio sit sic:

g postrema $\mathrm{R}$

h sed ... instanti add. i. marg. $\mathrm{R}$

i sic $\mathrm{R}$

j tempus $\mathrm{R}$

k om. P

1 aeterna $\mathrm{R}$

m ubi R

${ }^{n}$ voluerit $R$

o convenit $\mathrm{P}$

$\mathrm{P}$ possumus $\mathrm{P}$

47 Cf. e.g. Homeliae in Matt., hom. 18: «syn to anarcho Patri ...» (PG 57, 274).

48 Augustinus, De diversis quaestionibus, q. 72 (CCL 44A, 208).

49 Vide Gen. 49,26. 
temporale et aeternum opponuntur. Unde de quolibet bene quaeritur aut est $^{\mathrm{q}}$ aeternum aut temporale. Et hoc est quod dicit Augustinus in supra dicta auctoritate De 83 quaestionibus: "Si enim tempora, quomodo aeterna?» ${ }^{50}$. Igitur cum constat quod mundus sit ${ }^{\mathrm{r}}$ temporalis, patet quod non est aeternus. Tempus enim non mensurat nisi esse mundi.

Item, dicit Aristoteles: «In perpetuis idem est esse et posse» ${ }^{51}$. 46 Multo magis in aeternis. Igitur omne aeternum habet quicquid habere potest. Sed omne habens quicquid habere potest necessario est invariabile et immutabile, quia si est mutabile, est possibile ut mutetur ab aliquo quod habet in aliquid quod non habet. Ergo omne aeternum est invariabile. Sed mundus continue variatur, quia numquam in eodem statu permanet, sicut nec minor mundus. Unde I Cor. $7<31>$ : 'Praeterit figura mundi huius'. Ergo mundus non est aeternus.

Item, omne quod potest redigi in nihil prius fuit nihil quam aliquid, non econtrario. Non enim omne quod fuit nihil priusquam aliquid potest redigi in nihil, quia anima et angelus, cum prius fuerunt nihil, non rediguntur in nihil; sed constat redigi in nihil non potest, nisi quod prius fuit nihil quam aliquid. Igitur similiter in non-ens redigi non potest, nisi quod prius fuit non-ens quam ens; sed mundus potest redigi in non-ens. Probatio: dicit Plato in Timaeo: «Omne coniunctum natura est dissolubile» ${ }^{52}$. Sed mundus est quoddam ${ }^{\mathrm{s}}$ coniunctum et compositum maxime. Ergo est dissolubilis natura. Ergo potest redigi, non dico in nihilum, sed in non-ens. Ergo prius habuit non-esse quam esse. Sed, ut dicunt, ab aeterno habuit mundus esse. Ergo ante aeternum est aliquid in quo habuit mundus non-esse — quod est falsum. Si enim est ${ }^{t}$ aeternum, nihil antecedit.

Item, si ab aeterno fuit mundus et homo, et ita infiniti homines praecesserunt. Igitur aut infinita sunt actu, scilicet infinitae animae

q om. R

$r$ est $\mathrm{R}$

$s$ quiddam $\mathrm{R}$

t om. R

50 Ibid.

51 Aristoteles, Phys. 3.3 (203b30); cf. J. HAmesse, Les Auctoritates (supra, nt. 31), p. 148 , no. 103 .

52 Plato, Tim. 33A (ed. Waszink, p. 25). 
- quod non concederet Aristoteles - aut una est omnium hominum anima aut in alia et in ${ }^{\mathrm{u}}$ alia revertuntur corpora aut corrumpentur ${ }^{\mathrm{v}}$, quorum quodlibet est impossibile ${ }^{53}$.

Item, dicit Aristoteles quod homines quanto moderniores tanto sunt ingenio perspicaciores ${ }^{54}$. Si igitur perspicacitas crevit et crescit, in quolibet praecedente tempore fuit in quolibet homine perspicacitas infinita. Quippe crementum per infinitum tempus necessario est infinitum, et sic de quolibet moderno homine - immo et de quolibet praeterito, quia quemlibet praesentem et praeteritum hominem praecesserunt infiniti. Verum est quod sit infinitae perspicacitatis quod est impossibile.

Consimiliter videmus quod homines quanto sunt moderniores tanto sunt secundum quantitatem corporis minores. Si ergo decrescit ${ }^{\mathrm{w}}$ corpus humanum in singulis generationibus, tamen secundum eos praecesserunt infinitae hominum generationes. Sequitur aut quod homines iam nullius sint quantitatis propter decrementum infinitum aut quod sint quantitatis ${ }^{\mathrm{x}}$ infinitae, et fuerint alioquin non poterunt in infinitum decrescere. Finita enim quantitas in infinitum decrescere non potest. Ita dico ut in ea salvetur species humani corporis.

Scio enim quod quantitas dividi potest in infinitum, ut primo in duo media, et deinde medietas in duo media, et sic semper. Et tamen sic dividendo necessario venietur aliquando ante infinitam divisionem ad tam modicam quantitatem in qua neque carneitas salvari posset ${ }^{\mathrm{y}}$. Omnis enim forma naturalis quantitatem sibi determinat in qua salvetur et in minore salvari non posset.

Consimiliter videmus ex paucis hominibus in aliquanto finito tempore provenire magnam multitudinem, licet plures ex eis per mortem subtrahantur. Unde certi sumus quod multo plures nunc uniunt homines quam in temporibus patrum nostrorum. Igitur si secundum successionem temporis crescit et augetur numerus hominum, tunc in

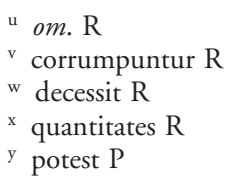

53 Cf. Grosseteste, Hexaemeron 1.8.7 (edd. Dales / Gieben, p. 62).

54 Non inveni. 
tanto tempore denumerato quantovis tempore ${ }^{\mathrm{z}}$, finito tantum ${ }^{\text {aa }}$ augetur, augetur ${ }^{\mathrm{bb}}$ numerus hominum simul entium. Sed in tempore praecedente, ut dicunt, infinito sunt infinita talia tempora, quia omne finitum, quantumcumque sit, est in infinito infinities. Ergo in quolibet tempore praecedente, quia illud praecessit tempus infinitum, fuerun ${ }^{\text {cc }}$ simul actu homines infiniti, et nunc sunt etiam, quod est impossibile, cum constet locum et maxime terrae superficiem in qua sunt homines esse finitum. Et sic generaliter, si aliqua condicio status humani recipit ${ }^{\mathrm{dd}}$ maioritatem et minoritatem ex successione temporis, tunc si est infinita temporis successio et hominum propagatio infinita, erit illa condicio <infinite> vel in parvitate vel in magnitudine.

Sed forte dicetur quod non oportet, licet ab aeterno, et infinitis retroactis temporibus fuerit mundus quod similiter homo, sed post infinita tempora transacta fuit ${ }^{\mathrm{ee}}$ homo.

Sed hoc constat non dicerent. Si enim aliqua constellatio facta per stellarum revolutiones fuit causa, producens homines in esse ex materia secundum illud Aristotelis: "Homo generat hominem ex materia et sol» ${ }^{55}$, cum talis constellatio in praecedenti tempore infinito fuerit infinities, fuit et homo ante infinities. Si vero Deus immediate fecit hominem, et non generatus est homo ex Deo et virtute caelesti convenientibus, quaeratur $\mathrm{ab}$ eis quare tunc et non prius voluit hominem esse, cum esset tempus prius. Quaeratur etiam tunc de aliis animantibus, de quibus constat quod producantur in esse mediante virtute corporum caelestium.

Item, Aristoteles in principio Philosophiae primae, volens probare causas agentes sibi succedentes secundum ordinem esse infinitas, utitur tali argumento. Ponamus vel sumamus de infinitis causis agentibus, si sint $\mathrm{ff}^{\mathrm{ff}}$ infinitae, tres ordines sibi succedentes $a b c$, ita ut $b$ sit ab $a$

${ }^{z}$ dum tamen add. P

aa tanto P

bb om. P

cc fuerint $\mathrm{P}$

dd recepit $P$

ee fuerit $P$

ff sunt $\mathrm{R}$

55 Aristoteles, Phys. 2.2, $194 \mathrm{~b} 13$ (edd. Bossier / Brams, p. 55); cf. J. Hamesse, Les Auctoritates (supra, nt. 31), p. 145, no. 65. 
et $c \mathrm{ab} b$. Constat $c$ non est nisi sit $b$, neque $b$ nisi sit $a$. Igitur ultimum horum trium non est nisi sit horum medium, neque medium horum est nisi sit primum horum trium. Igitur sigg non est aliquid quod est primum horum trium, nihil horum trium est. Igitur si non est aliquid quod est primum omnium horum infinitorum, nullum eorum omnino erit. Sed si sint ${ }^{\text {th }}$ causae agentes infinitae, non est prima. Igitur si sunt infinitae, nulla omnino earum est.

Consimili argumento utamur et nos in proposito, ut omnibus modis Aristotelis ${ }^{\text {ii }}$ concludatur, quia si dicit argumentum non valere cum suum sit, concludatur. Si concedit valere, neget mundum aeternum esse - quod posuit; si mundus ab aeterno fuit, fuerunt revolutiones caeli ab aeterno sibi succedentes infinitae, de quibus infinitis, sumptis tribus sibi propinquis revolutionibus $a b c$, verum est dicere sicut de causis: non est $c$ nisi post $b$, nec $b$ nisi post $a$. Igitur si non esset prima horum trium revolutionum, nulla harum fuisset.

Igitur a simili: si non est prima omnium harum revolutionum demonstratis centum, nulla earum est. Igitur similiter de infinitis. Si non est prima infinitarum revolutionum, nulla earum est. Sed si fuerunt infinitae, non fuit prima. Igitur si fuerunt infinitae caeli revolutiones, nulla fuit omnino.

Item, revolutio, quae nunc est et est ultima earum quae fuerunt, vocetur $a$. Si igitur infinitae revolutiones sibi succedentes praecesserunt $a$, necessario numquam perveniretur ad $a$ revolutionem; et ita $a$ revolutio nondum est nec erit; eadem ratione nec praecedens proximam nec illam adhuc praecedens et sic de qualibet. Et ita si infinitae fuerunt revolutiones, nulla est vel erit vel fuit.

Item, novimus aliquid carere principio et fine, ut Deum; novimus et aliquid habere principium et finem, ut hanc plantam. Novimus aliquid habere initium sed non finem, ut animam. Quartum autem esse non novimus, scilicet habens finem et non principium. Igitur si omnes revolutiones quae fuerunt habent finem hanc, scilicet quae nunc est, necessario habuerunt primam. Sic ergo significatione huius distinctionis "principio" destruit $\mathrm{j}^{\mathrm{j}}$ tantorum tam magnos errores Moyses. Nec non consignificatione etiam eiusdem, scilicet numero

\footnotetext{
gg si non est aliquid: nisi sit illud $\mathrm{P}$

hh sunt R; corr. ex sunt P

ii Aristoteli $\mathrm{R}$

ij destruxit $\mathrm{P}$
} 
singulari multorum et magnorum, elidit errores qui non unicum posuerunt principium omnium, scilicet Deum, sed plura, ut Aristoteles, qui posuit materiam et speciem et tertium, dictum «operatorium " ${ }^{56}$, et Plato hylem, ideam, et deum, et ita materiam et formam ${ }^{57}$. Posuerunt Aristotelici quod ipsa et a nullo essent et sine initio temporis, sed ${ }^{\mathrm{kk}}$ Deo coaequa, ut patet ex Ambrosio in Hexaemeron in principio ${ }^{58}$. Quos philosophos Hieronymus et Beda super idem reprehenderunt ${ }^{5911}$. Similiter "Thales Milesius aquam posuit omnium principium quae sine initio et a nullo esset et hic omnia elementa mundi et ipsum mundum et quae in eo gignuntur existere. Nihil autem huic operi quod mundo considerato tam mirabile aspicimus, ex divina mente praeposuit; Anaximander vero unicuique rei propria posuit principia, et innumerabiles mundos ex ipsis esse; nihilque divinum eis praeposuit; Anaximenes vero aeri finito omnium rerum causam dedit; neque deos negavit aut tacuit; non tamen ab ipsis aerem factum, sed ipsos ex aere ortos credidit. Anaxagoras vero rerum omnium quas videmus effectorem divinum, animum sensit, et ex infinita materia, quae constaret similibus inter se particulis, sed animo faciente divino. Diogenes vero aerem dixit rerum materiam esse de qua omnia fierent, sed eum compotem esse divinae rationis sine qua nihil ex eo fieri posset. Archilaus autem ipse et de particulis inter se similibus, quibus singula quaeque fierent, ita putavit constare omnia ut in esse etiam mentem diceret, quae corpora aeterna, id est illas particulas, coniungendo et dissipando ageret omnia ${ }^{60}$.

«Horum omnium errores elidit unica littera», scilicet littera terminali huius distinctionis: "principio», quo ${ }^{\mathrm{mm}}$ numerus singularis

\footnotetext{
kk scilicet P

${ }^{11}$ reprehendunt $\mathrm{P}$

mm qua $P$
}

56 Petrus Lombardus, 2 Sent. 1.3 (p. 331).

57 Ibid., cap. 1 (p. 330).

58 Ambrosius, Hexaemeron 1.1.1 (CSEL 32.1,3).

59 For the problem of the source that went under the name of «Hieronymus» or "Hieronymus et Beda», cf. John T. MUCKLE, "Did Robert Grosseteste attribute the Hexaemeron of St. Venerable Bede to St. Jerome?», in: Mediaeval Studies 13 (1951), pp. 24244; and Richard C. DALES, Introduction to edition of Grosseteste's Hexaemeron, p. xxiii.

${ }^{60}$ Grosseteste, Hexaemeron 1.9.3 (edd. Dales / Gieben, p. 64); cf. Augustinus, De civ. Dei 8.2 (CCL 47, 217-218). 
designatur. "Mirabilis prorsus est huius sapientiae profunditas inscrutabilis quae unica littera tantam prosternit catervam errorum. Neque oportet destructioni horum errorum insistere, cum ipsi ${ }^{\mathrm{nn}}$ se ipsos destruant mutuo. Unde Basilius: Plurima super rerum naturam Graecorum philosophi disputaverunt, sed nullus apud eos sermo fixus habetur et stabilis, priore semper a sequente deiecto; nihilque nobis operae pretium est, quae illorum sunt infirmare, cum ad destructionem propriam sibimet ipsi sufficiant ${ }^{61}$.

$\mathrm{nn} \quad$ isti $\mathrm{R}$

61 Basilius, Hex. 1.2 .2 (p. 5); coll. ex Grosseteste, ibid. 


\section{APPENDIX B}

Richard Rufus, In 2 Sent. 1.1 (ed. Stephen F. Brown, «The Eternity of the World Discussion at Early Oxford», in: A. ZimMERMANN et A. SpeER (edd.), Mensch und Natur im Mittelalter (Miscellanea Mediaevalia 21/1), Berlin-New York 1991, pp. 270-276).

\section{[Quaestio prima: An sit creatio?]}

Sit ergo nobis quaestio in medio proposita in principio: an sit 1 creatio omnino aut non sit.

Quod $^{1}$ non sit videtur, nam omne quod fit fit $a$ et ex sibi conve- 2 nienti. Non est autem convenientia inter nihil et aliquid. Ergo ex nihilo non fit aliquid. Et hoc est quod posuerunt fere omnes philosophi, scilicet ex nihilo nihil fit. Quid autem est creatura? Augustinus, Contra Felicianum: "Creatura est, ex eo quod adhuc non est, aut aliquando non fuit, rei cuiuslibet corruptibilis, quantum in se, est Dei Patris omnipotentis voluntate facta substantia». - Sed puto ad praedictum argumentum quod illa ${ }^{2}$ propositio "quod fit fit» etc., in causa agente per se, et non secundum accidens, sive mediata sive immediata, universaliter vera est. Sed non in genere causae materialis universaliter est vera: non enim omne quod fit ex materia fit. Et cum dicimus aliquid fieri ex vel de nihilo, non notatur ibi circumstantia causae materialis, sed accipitur ibi «ex», id ${ }^{3}$ est "post», sicut: ex nocte fit dies.

Item, actio non exigit quid agat, sed in quid; ita dicit Philosophus. 3 Ex quo videtur quod creare exigat materiam substantialem, et ita ut prius. - Sed puto quod illud intelligendum est de actione artificis diminuti, qui scilicet indiget necessario materia subiecta. Non est autem hoc nomen de actione Dei, scilicet creatione; sed econverso illa exigit quid agatur et non in quid.

Item, posita tota et plena causa alicuius, necesse est totum et ple- 4 num effectum eiusdem causae simul cum ea coexsistere. Deus autem

\footnotetext{
${ }^{1}$ quid $e d$.

2 om. ed.

3 id est post: [ex] I Posteriorum $e d$.
} 
talis causa est, quia omnipotens est, cui nulla accidit nova condicio vel sapientiae vel potentiae vel voluntatis. Ergo si mundus ab eo factus est, semper simul cum eo coexsistit, et est aeternus.

Hic solvunt aliqui quod haec ratio necessaria est in his quae participant mensuram eiusdem generis, utpote quod ambo sint temporalia vel ambo aeterna. "Si autem causa et causatum non participent eiusdem generis essendi mensuram non potest eis coaptari illa regula, ut dicatur: 'exsistente causa, necessario coexsistit causatum'». Tempus vero et aeternitas non sunt eiusdem generis mensurae, et ideo in his non tenet. Sed in Patre et Filio "quorum uterque aeternus, et Pater causa Filii, secundum Augustinum, Damascenum et Chrysostomum", ambo coaeterni sunt. Sed "Deus aeternus causa est mundi temporalis et praecedit mundum non tempore sed simplici aeternitate».

Sed contra hanc responsionem quaerunt quidam: "cum causa temporalis possit facere suum causatum esse simul tempore cum ipsa, quare non similiter causa aeterna sufficiens possit facere suum causatum sibi coaeternum, cum causa aeterna in infinitum sit potentior causa temporali?» — Sed haec quaestio mihi videtur nulla, nam hoc est quaerere quare Deus non possit facere temporale aeternum.

Respondi tamen potest ad praedictam quaestionem aliter, ut videtur, quod dupliciter est causa vel principium rei: principium naturale agit sine ratione et agit necessitate. Et ideo posita tali causa sufficiente, statim ponitur effectus. Causa autem voluntaria non agit necessitate sed pure voluntarie et cum potestate rationabili quae semper valet ad opposita. Et praeterea, nulla necessitas accidit in Deo; unde in ipso non tenet propositio praedicta.

Item, sicut arguit Augustinus, Contra Maximinum, ut habitum est I libro, d. 20, quaero: Deus aut potuit creare mundum sibi coaeternum aut non? Si non, impotens fuit. Si sic: aut noluit, et tunc invidit; aut voluit, et tunc fecit. - Sed ad istud iam responsum est, ut videtur, quia hoc posse esset posse facere temporale aeternum et creaturam Deum, et hoc est potius ${ }^{4}$ non posse.

Item, idem eodem modo se habens semper natum est idem facere. 9 Ergo Deus qua ratione tunc fecit mundum et semper fecit et faciet. Et sic videtur quod aut numquam creandus fuit mundus aut $a b$ aeterno, quia ex parte Dei non est ratio aliqua, ut videtur, quare nunc

\footnotetext{
${ }^{4}$ post ed.
} 
et non prius, cum omnino similiter semper se habeat; nec in re facienda erat causa quia ipsa nihil fuit.

Ad istud respondent aliqui quare "tunc et non prius creavit mundum, quia sic fuit optimum». Et quare hoc? "Quia Deus sic voluit», cuius voluntatis causa alia non est. Vel aliter: "haec quaestio fundatur super falsam imaginationem qua imaginatur tempus fuisse ante mundum». Et hanc quaestionem recitat Augustinus, De civitate Dei, libro XI, cap. 5, dicens: «Ita quaeritur cur potius tunc et non antea factus sit mundus, quemadmodum quaeri potest cur hic potius ubi est et non alibi. Nam si infinita spatia temporis ante mundum cogitant ... cogitent similiter extra mundum infinita spatia locorum. Nunc autem nec extra mundum est locus, nec ante mundum fuit tempus». Unde Augustinus, libro eodem et capitulo eodem: "Quis non videat quod tempora non fuissent nisi creatura fieret, quae aliqua motione mutaretur?» - Omnino mihi videtur, ut prius, quod haec quaestio nulla est: quare, scilicet, tunc et non prius fecit mundum? Hoc est enim quaerere quare non ab aeterno fecit mundum: nihil enim prius mundo nisi aeternum. Ab aeterno ergo voluit Deus voluntate incommutabili mundum esse non ab aeterno, sed ex tempore, hoc est quando mundum esse possibile est. Cum ergo quaeritur an fuit causa in Deo quare non prius fecit mundum, verum videtur quod in ipso fuit causa. Haec enim videtur causa, quia scilicet ipse solus es aeternus. Unde sua aeternitas et sua incommutabilitas videtur causa quare non fecit mundum ab aeterno. Unde Augustinus, libro eodem, cap. 4: «Sic credant et mundum ex tempore fieri potuisse, non tamen ideo Deum in eo faciendo aeternum consilium voluntatemque mutasse».

Item, si mundus incepit, prius fuit verum mundum non esse et postea fuit verum mundum esse; "prius» autem et "posterius» sunt differre ${ }^{5}$ temporis; fuit igitur tempus ante mundi creationem. Aut aliter ducitur haec oppositio: «si est primum instans temporis et mundi, in illo instanti quod vocetur 'a', verum fuit mundum esse et prius fuit verum mundum non esse. Aut ergo in eodem instanti aut in alio. Si in eodem, contra: affirmatio et negatio quae sunt termini generationis minus distant quam quae sunt termini creationis; illae enim causae habent saltem materiam; secundae vero nibil omnino, quia creatio est

5 differentiae $e d$. 
ex nihilo. Cum igitur esse et non esse quae sunt termini generationis in eodem instanti simul esse non possint, multo magis esse et non-esse quae sunt termini creationis simul esse non poterunt. Igitur, ambo ista 'mundum esse' et '[mundum] non esse' non sunt vera in primo instanti temporis; igitur 'mundum non esse' fuit verum in alio instanti praecedenti primum instans. Et inter haec duo instantia erit tempus medium; ergo ante primum instans temporis [tempus] est; quare tempus est ab aeterno".

Hic respondetur quod in omni creato non esse praecedit esse; sed in quibusdam non esse praecedit esse tempore, ut in animabus quae nunc creantur; in quibusdam vero non esse praecedit esse solum natura seu aeternitate. Cum ergo in primo creato dicitur prius non esse quam esse non affirmatur et negatur esse respectu eiusdem mensurae, sed esse negatum dicit nunc aeternitatis, esse affirmatum primum nunc temporis. Unde inter ista duo nunc non est tempus medium. Isti responsioni hucusque consentio. Sed isti idem addunt aliquid de subtili quod non verum esse intelligo. Dicunt enim quod «in primo nunc temporis simul sunt esse et non-esse primae creaturae, et generaliter de omnibus creatis de nibilo». Consimile ${ }^{6}$ dant iudicium quod putant probare sic: Omne quod est solum natura prius alio, nihil prohibet ipsum esse simul tempore cum illo. Sed non esse primi creati solum natura prius est quam esse eiusdem; ergo etc. - Non credo quod istud teneat. Non enim sequitur nisi si illud quod] est solum natura prius non est tempore prius. Sed ultra non sequitur: «non est tempore prius illo, ergo potest esse tempore simul cum illo", nam non-esse nec est prius tempore, nec simul tempore cum illo. Magis adhuc conantur explanare quod dicunt: «non-esse, cum sit pura negatio, de se nullam quaerit mensuram; esse vero quaerit. Igitur esse et non-esse, si quaerunt distinctionem secundum tempus, hoc non erit nisi quia illud non-esse ponit aliquid, scilicet aliquod esse aliud ab esse negato. Ita est in extremis generationis", nam ibi est primo quidem esse in potentia, deinde vero esse in actu, et ista esse diversa sunt causae diversorum nunc temporis. Sed nonesse quod est extremum creationis ${ }^{7}$ [est] pura negatio, et non ponit aliquod esse; unde non est causa alicuius nunc temporis. Sed aliud

\footnotetext{
${ }^{6}$ consimilem $e d$.

7 dictionis $e d$.
} 
extremum creationis, scilicet esse est causa unius nunc temporis. Sic ergo in his utrisque sufficit unum nunc temporis, et compatiuntur se in uno. Et exemplificat in hoc de luce: quod ipsa eodem numero «in eodem nunc temporis est in oriente et occidente, tamen prius natura in oriente». - De hoc exemplo dictum est primo libro, dist. 37M, quod falsum est quod hic dicitur de luce, et similiter de angelo.

Item, satis mirum ${ }^{8}$ videtur quod dicunt non esse quod est pura negatio et esse de eodem subiecto simul esse vera, cum $^{9}$ affirmatio et negatio de nullo eodem simul sint verae. Nec hoc capit intellectus aliquis omnino, scilicet quod de eodem simul affirmatio et negatio.

Item, non-esse quod est extremum generationis, si supponit aliquod esse, ergo non est simpliciter negative, quia ex pure negativa numquam sequitur affirmativa. Quod si hoc, non contradicit esse affirmato. Ergo, si debet contradicere, omnino nihil ponet.

Item, si negatio potest esse vera cum contradictoria affirmatione, pari ratione poterit affirmatio esse vera cum contradictoria negatione. $\mathrm{Si}$ enim compatiuntur se in eodem nunc temporis, possunt et se compati in nunc aeternitatis. Ex quo sequitur quod mundum esse fuit verum ab aeterno. Distinguit Augustinus, in libro Confessionum XII G, "prius» et "posterius» quattuor modis: aeternitate, tempore, electione, origine. Aeternitate: sicut Deus omnia; tempore, sicut flos fructuum; electione, sicut fructus florem; origine, sicut sonus cantum. - Haec praedicta mihi non placent, sed magis videtur quod non-esse mundi, si praecedit ${ }^{10}$ esse, non tempore praecedit, nam non est tempus ante mundum; sed praecedit natura seu aeternitate, quia ab aeterno verum fuit non esse mundum, et esse ${ }^{11}$ mundum est posterius, tempore scilicet, nam et ipsum tempus posterius est aeternitate. Posterius, dico, se ipso tempore, ut iste ablativus designet rationem mensurae, et aeternitas est prior tempore, se ipsa aeternitate. Nec sequitur: $a$ est aeternitate prius ipso $b$; ergo $b$ est aeternitate posterius ipso $a$; et hoc tum quia in aeternitate non est prius et posterius, tum quia aeternitas non communicatur ab utroque, scilicet $a$ et $b$.

\footnotetext{
8 manifestum ed.

9 tamen $e d$.

10 praecederet $e d$.

11 om. ed.
} 
His ergo dimissis, redeamus ad obiectiones. $\quad 16$

Si mundus finem non habet, ergo nec initium, nam dicit Ambro- 17 sius, Hexaemeron, homelia prima: "Quae initium habent, et finem habent; et quibus finis datur, initium dari constat». Ecce quod convertuntur "habere initium» et "habere finem».

Et idem ${ }^{12}$ Basilius, in Hexaemeron, homelia prima: Omnia quae ex tempore ceperunt, necesse est tempore terminari. Si est initium temporale, de fine non dubitatur ${ }^{13}$.

Unde Damascenus: Omne quod incipit et finitur per naturam.

Sed puto quod haec intelligenda sunt secundum naturam ${ }^{14}$ ipsorum creatorum. Sunt tamen aliqua quae habent initium et non finem. Sed hoc est per conditoris voluntatem, ut innuit illa sententia Platonis supra. Et idem Plato in Timaeo: "Corpora caelestia natura sunt dissolubilia, voluntate autem conditoris indissolubilia».

Item, si est creatio, creat Deus postquam non creavit, et movet postquam non movit; ergo factus est de non-movente movens; ergo est mutabilis. Aut si ab aeterno movet, movere autem et moveri correlativa sunt et simul natura, ergo ab aeterno est motus.

Hic iterum dicunt aliqui quod Deus fuit motor ab aeterno et movens. Unde motor vel movere non incepit esse. Sed tamen motus incepit esse: movere enim natura prius est quam moveri, sicut actio quam passio: est enim eius causa. - Istud iterum mihi non placet, quia Deus incepit esse Dominus, sicut docet Augustinus, sic et incepit creare et movere et agere. Unde Augustinus, Confessionum, libro XI: "Audenter dico 'antequam faceret Deus caelum et terram, non faciebat aliquid'. Si enim faciebat, quid nisi creaturam faciebat? Sic ergo incepit creare, movere, et agere». Sed haec verba «movere», "agere», non proprie dicuntur de Deo, sicut hic docet Magister in secunda parte distinctionis: non enim agit Deus instrumentis corporalibus sed verbo - 'dixit enim et facta sunt'. Ab aeterno autem dixit, ut fieret mundus tunc quando esse incepit. Ipse ergo semper uniformiter se habuit et ante et post: non enim aliter movit vel fecit cum creavit quam ante. Sed tunc factum est quod non ante. Ex his

\footnotetext{
12 ideo $e d$.

13 est dubitandum $e d$.

14 natura $e d$.

15 passibibile (sic) ed.

16 n quantum ed.
} 
patet quod nulla est in ipso mutatio etsi nunc quidem sit creans, prius vero non. Sed in ipso creato est mutatio, scilicet de non-esse ad esse.

Item, si creat et agit Deus, erit ibi actio, ergo et passio, et patiens; quare et passivum sive passibile. Est autem natura prius passibile quam patiens, sicut combustibile quam combustum. Quaero ergo: Potentia quae notatur in hoc ipso passibile, ratione cuius est passibile ${ }^{15}$ prius natura quam patiens, in quo est inquam ${ }^{16}$ haec potentia? Aut in aliquo aut in nihilo? $\mathrm{Si}$ in aliquo, ergo prius fuit aliquid antequam crearetur. $\mathrm{Si}$ in nihilo, ergo ipsum nihil est passibile, et erit patiens. Quare, ipsum nihil creabitur et fiet. - Hic puto quod istud passibile non est priusquam patiens, nec proprie dicitur hic ${ }^{17}$ passibile vel patiens; - sed dicatur creabile et creatum. Et puto quod creabile non est prius creato natura vel tempore, sed aut ${ }^{18}$ solum secundum modum intelligendi. Talis enim regula, puto, non tenet nisi in eis quae sunt ${ }^{19}$ prius in potentia, deinde in actu; hoc est in eis quae habent causas seminales in materia praeiacenti. Ipsa autem prima creatura non prius fuit creabilis, nec in potentia, nec passiva nec activa, nam ipse Deus etiam non potuit prius creare primam creaturam: hoc enim esset ab aeterno creare - hoc opposito in adiecto. Melius sic dicitur: mundus fuit creabilis ab aeterno, hoc est, fuit subiectus scientiae Dei et tale esse habuit. Sed non fuit creatus ab aeterno, id est, non habuit esse in materia. Et est unum prius altero; et est haec positio in mundo et in aliquo. Nec tamen mundus est ab aeterno nisi praedicto modo.

\footnotetext{
17 hoc ed.

18 om. ed.

19 sunt ... in eis quae om. ed.
} 